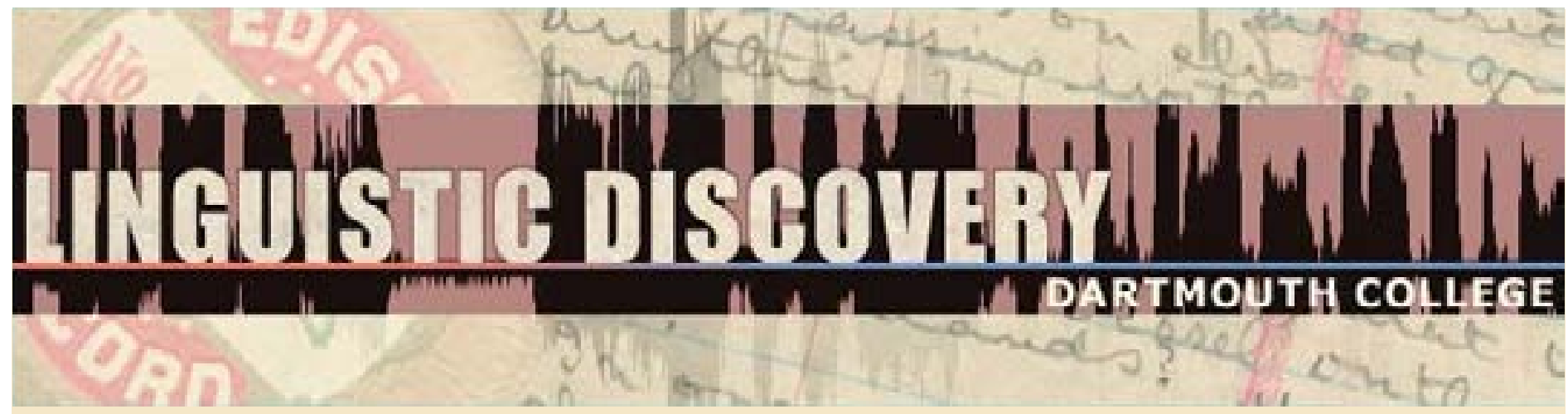

\begin{tabular}{|l|}
\hline Volume 9 \\
Issue 1 \\
2011 \\
\hline
\end{tabular}

\title{
Downstep in Tiriki
}

Mary Paster and Yuni Kim

Pomona College and University of Manchester

doi: 10.1349/PS1.1537-0852.A.390

url: http://journals.dartmouth.edu/cgi-bin/WebObjects/ Journals.woa/1/xmlpage/1/article/390 


\title{
Downstep in Tiriki* \\ Mary Paster and Yuni Kim
}

\author{
Pomona College and University of Manchester
}

In this paper, we present an analysis of the tone system of Tiriki, a Bantu language spoken in Kenya and previously undescribed in the linguistic literature. We focus on downstep, a complex phenomenon that arises in a number of different and interesting ways in this language. We claim that tone in Tiriki is best analyzed in a model where downstep is represented phonologically by a floating low $(L)$ tone between two high $(H)$ tones. This constitutes a divergence from many previous analyses of tone in Bantu languages, where there is often no phonological L tone at all, and where downstep is commonly analyzed as the phonetic interpretation of two adjacent $H$ tones. Crucial to our analysis is the observation that downstepped $H$ tones in Tiriki alternate not only with underlyingly specified L tones, but also with default L tones assigned to syllables that are underlyingly toneless. The data provide evidence that insertion of default tones is not, as usually assumed in the literature, universally limited to being an intrinsically late phonological rule or a matter of phonetic implementation. Rather, default tone insertion in Tiriki is a fullfledged phonological process that can and does interact with other phonological processes.

\section{Introduction}

In this paper, we present an analysis of the tone system of Tiriki, a Bantu language spoken in Kenya and previously undescribed in the linguistic literature. We focus on downstep, a complex phenomenon that arises in a number of different and interesting ways in this language. We claim that tone in Tiriki is best analyzed in a model where downstep is represented phonologically by a floating low $(\mathrm{L})$ tone between two high $(\mathrm{H})$ tones. This constitutes a divergence from many previous analyses of tone in Bantu languages, where there is often no phonological L tone at all, and where downstep is commonly analyzed as the phonetic interpretation of two adjacent $\mathrm{H}$ tones.

Crucial to our analysis is the observation that downstepped $\mathrm{H}$ tones $\left({ }^{\prime} \mathrm{H}\right)$ in Tiriki alternate not only with underlyingly specified L tones, but also with default L tones assigned to syllables that are underlyingly toneless $(\varnothing)$. The data provide evidence that insertion of default tones is not, as usually assumed in the literature, universally limited to being an intrinsically late phonological rule or a matter of phonetic implementation (cf. Yip 2002:63). Rather, given the three-way underlying tone contrast between $\mathrm{L}, \varnothing$, and $\mathrm{H}$, a clear case emerges that default tone insertion in Tiriki is a full-fledged phonological process that can and does interact with other phonological processes. ${ }^{1}$

\footnotetext{
*We are very grateful to our Tiriki consultant Francis Guguni for his time and patience, and to Larry Hyman, who participated in most of our elicitation sessions and was instrumental in guiding our research. We also thank Dave Odden, Michael Marlo, and the anonymous reviewers, who provided extensive feedback on previous drafts of this paper. Lee Bickmore, Sharon Inkelas, David Mortensen, Scott Myers, members of the UC Berkeley Phonology Forum, and the audience at ACAL 37 gave us a number of helpful comments on earlier versions of this research. All errors are, of course, our own responsibility.

${ }^{1}$ In fact, it may turn out that "default" is not the best term for how underlyingly toneless moras get a $\mathrm{L}$ tone in Tiriki, or indeed in other languages, because some readers may see an inherent implication in the term "default" that the output of a "default rule" is phonologically inert. We therefore wish to clarify that in using the term "default rule"
} 
The structure of this paper is as follows. In $\$ 2$, we contrast two previous approaches to downstep. $\$ 3$ presents the tonal phonology of Tiriki and shows how all of the various contexts for downstep receive a unified analysis in terms of a representation with floating L tones. In $\S 4$ we consider the applicability of our analysis to other languages, and in $\$ 5$ we discuss ways in which our approach is compatible with previous proposals for analyzing downstep and then conclude the paper.

\section{Representing Downstep}

Downstep is a phenomenon where a tone is realized at a lower pitch level than other tones of the same phonological category. For example, in a sequence of High + downstepped High $\left(H{ }^{!} H\right)$, the second tone is realized on a lower pitch than the first. That this is downstep, rather than a separate tonal level such as Mid, can be established if the language productively permits chains of downsteps $\left(\mathrm{H}{ }^{\prime} \mathrm{H}{ }^{\prime} \mathrm{H}{ }^{\prime} \mathrm{H} . ..\right)$, i.e., a 'theoretically... infinite number of non-low tone levels' (Hyman 1979a: 11). An example of this is seen in Shambaa, where sequences of adjacent $\mathrm{H}$ tones have downsteps between them, sometimes resulting in long sequences of successively downstepped $\mathrm{H}$ tones, as in (1) (Odden 1986: 363).

$$
\begin{array}{ll}
\text { ygó tó } & \text { 'sheep' } \\
\text { dú } & \text { 'only' } \\
\text { ízafá } & \text { 'they died' } \\
\text { ygó tó !dú 'ízafá } & \text { 'Only sheep died.' }
\end{array}
$$

While downstep as a surface empirical phenomenon is widely attested, the precise phonological representations giving rise to it have been more controversial. Unassociated, "floating" L tones have been argued to be the source of downstep in many languages, including Ngizim (Schuh 1971, Hyman and Schuh 1974), languages of the Mbam-Nkam group (Hyman and Tadadjeu 1976), Bade (Schuh 1978), Etsako (Elimelech 1978), Twi (Hyman 1979a), Babanki (Hyman 1979b), Aghem (Hyman 1986a), Kenyang (Odden 1988), Dagbani (Hyman 1993a), and Gã (Paster 2003); a floating-L analysis of downstep is also proposed by Pulleyblank (1986:27-64) for Tiv and Dschang. Arguments supporting this approach center around the fact that $\mathrm{H}{ }^{\prime} \mathrm{H}$ often has a synchronic relationship with HLH, so that there is independent evidence for the presence of a phonological $\mathrm{L}$ tone in sequences displaying downstep. ${ }^{2}$

For example, in Gã, underlying /HLH/ surfaces as $\mathrm{H}^{\prime} \mathrm{HH}$. The verbs in (2a) are shown in the past tense, preceded by the L-toned 3sg subject marker /e-/, where their underlying LH surfaces unchanged. In (2b), the subjunctive marker imposes a $\mathrm{H}$ tone on the subject marker, yielding an underlying /H-LH/ tone pattern, which surfaces as $\mathrm{H}$ 'HH. Paster (2003) analyzes this by positing a rule of Plateauing, whereby a L tone is delinked from its host mora when it occurs between two $\mathrm{H}$-toned moras, and the $\mathrm{H}$ of the rightmost mora spreads onto the previously L-toned mora. The unlinked L tone remains in the phonological representation, resulting in a downstep between the two $\mathrm{H}$ tones.

we mean to say only that default $\mathrm{L}$ insertion supplies a $\mathrm{L}$ tone just in case previous rules have not filled in a tone feature for a particular tone-bearing unit.

${ }^{2}$ Hyman and Schuh (1974) and Hyman (1979a:14) also observe that a lost L-toned element between two H tones can be the diachronic source of downstep. 


$\begin{array}{ll}\begin{array}{l}\text { e-hulú } \\ \text { e-kojó }\end{array} & \begin{array}{l}\text { 'he jumped' } \\ \text { e-majá } \\ \text { e-basá }\end{array} \\ \begin{array}{l}\text { 'he sent' } \\ \text { 'he grabbed' }\end{array} \\ \text { é-'húlú } & \text { 'that he jump' } \\ \text { é-'kójó } & \text { 'that he judge' } \\ \text { é-'májá } & \text { 'that he send' } \\ \text { é-'básá } & \text { 'that he grab' }\end{array}$

The examples in (3a) are underlyingly $\mathrm{H}$-toned verbs in the past tense. These surface with their tones unchanged, confirming that the initial $\mathrm{L}$ on the /LH/ verbs in $(2 \mathrm{a})$ is inherent to the verb roots rather than arising due to the $\mathrm{L}$ of the subject marker in the past. The examples in (3b) are underlyingly $\mathrm{H}$-toned verbs that also surface unchanged in the subjunctive, confirming that the downstep in (2b) comes from an underlying $L$ tone on the verb root rather than from any general process inserting a downstep between underlying $\mathrm{H}$ tones in Gã (note: underlining indicates contrastive nasalization).

\begin{tabular}{|c|c|c|}
\hline (3a) & e-lá & 'he sang' \\
\hline & e-dú & 'he cultivated' \\
\hline & e-yóó & 'he recognized' \\
\hline & e-fóté & 'he poured' \\
\hline (3b) & é-lá & 'that he sing' \\
\hline & é-dú & 'that he cultivate' \\
\hline & é-yóó & 'that he recognize' \\
\hline & é-fóté & 'that he pour' \\
\hline
\end{tabular}

We refer the reader to Gussenhoven (2004: 101-103) for further discussion of languages where downstep is analyzed as involving a floating $L$ tone.

For other languages, it has been argued that no floating $L$ tone is involved in downstep and that instead, downstep is simply the phonetic implementation of a sequence of $\mathrm{H}$ tones. For example, Bickmore (2000; on Namwanga) and Carlson (1983; on Supyire) assume that downstep results automatically when two $\mathrm{H}$ tones are adjacent to each other. ${ }^{3}$ In that approach, instances of adjacent $\mathrm{H}$ tones with no downstep are analyzed as context-dependent fusion of adjacent H's into a single $\mathrm{H}$. With fusion, the phonetic implementation mechanism receives only a single $\mathrm{H}$ as input and therefore there is no downstep on the second $\mathrm{H}$. The difference between distinct and fused $\mathrm{H}$ tones is shown in the following example from Namwanga (Bickmore 2000: 303).

\footnotetext{
${ }^{3}$ Bickmore proposes that Namwanga '... tolerates structural violations of the Obligatory Contour Principle (Leben 1973) in the output of the phonology. When the phonetic component encounters two consecutive TBUs linked to distinct H's, a downstep is realised between them, whereas two consecutive TBUs linked to a single $\mathrm{H}$ are realised on the same pitch' (2000: 302).
} 


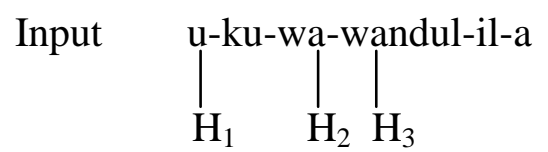

Output ú-kú-'wá-wán-dúl-íll-à 'to blacksmith for them'

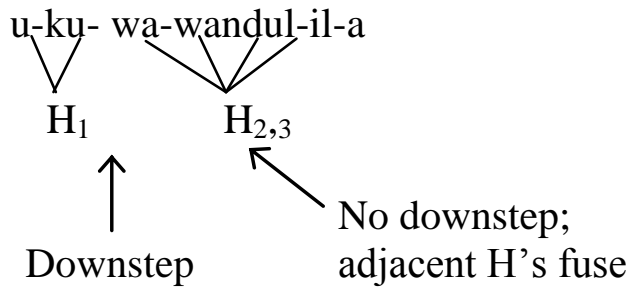

between H's

This proposal, which we will call the "Separate-H" analysis, is the primary analysis with which we will contrast our own analysis in this paper. Note that in order to focus on the Tiriki generalizations of interest here, we assume the simplest possible representation of $\mathrm{H}$ and $\mathrm{L}$ tones as primitive units, i.e. consisting only of individual tone features $\mathrm{H}$ and $\mathrm{L}$. We will leave open the possibility that our proposal can be elaborated to involve register features such as those discussed in van der Hulst and Snider 1993, given that register-based approaches also represent downstep by means of phonological low tones (albeit of a different kind).

\subsection{Predictions of Floating-L and Separate-H}

The Floating-L and Separate-H analyses are schematized in (5). In many respects, they make similar empirical predictions. Proponents of both agree that downstep, as a categorical phonological phenomenon, must be assigned a representation that distinguishes it from nondownstep contexts (see e.g. Liberman and Pierrehumbert 1984). Furthermore, there is general agreement that downstep should be represented by some configuration of independently existing tonal primitives, and that downstep results from the phonetic implementation of this configuration (see e.g. Gussenhoven 2004:105). One line of evidence in favor of considering downstep as arising in the phonetic component, and against representing it as a phonological primitive, comes from the fact that the 'rule' of downstep never seems to feed any other established phonological rules. For example, rules triggered by $\mathrm{H}$ tones are also triggered by downstepped $\mathrm{H}$ tones. If downstep changed the phonological representation of an underlying $\mathrm{H}$ tone, we would expect that later phonological rules should be sensitive to the difference between downstepped vs. non-downstepped H tones; no such cases are known. See Pulleyblank (1986:62) and Yip (2002:151) for similar argumentation.

(5a) Floating-L analysis

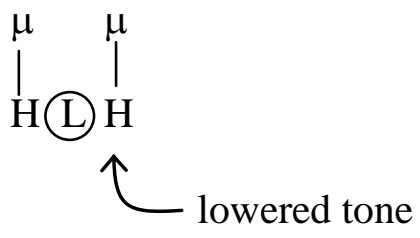


Separate- $\mathrm{H}$ analysis

$\mu \mu$

$\mathrm{H} \mathrm{H}$

\section{lowered tone}

Given the similarities, it is important to consider on what basis one might choose between these two representational options, and whether the choice matters. Because a floating L tone is not associated to any TBU and does not in itself constitute a surface pitch target, these two representations do not make different phonetic predictions with regard to categorical processes of downstep. Thus, in contrast to many other questions of presence vs. absence in phonological representations (see, e.g., Myers 1998), the two analyses cannot be distinguished on the basis of an experimental phonetic investigation.

While (5a) may be an intuitively less arbitrary representation of downstep than (5b) because the former appears to contain a phonological indication of pitch-lowering and the latter does not, there is no obvious way to directly connect the floating L tone to the observed downstep in the absence of an explicit theory of the phonetic interpretation of unlinked tonal elements. One might argue that floating tones should only be able to cause the phonetic component to manipulate pitch in the direction of the tonal range that it specifies; in that case, (5a) could only give rise to downstep, whereas the interpretation of (5b) as downstep or upstep would be language-specific - perhaps a more desirable result since we would otherwise lack a formal representation for upstep. However, one might equally argue that a floating L tone could trigger dissimilatory upstep of a following linked $\mathrm{H}$ tone. Without empirically justified restrictions on how floating tones are mapped to the phonetics, this does not seem to be a fruitful avenue of argumentation, and therefore it does not help us in distinguishing the two types of analysis.

Another possible argument in favor of the Separate- $\mathrm{H}$ analysis is that the Floating- $\mathrm{L}$ analysis is too abstract, or even circular: if the only evidence for floating $L$ tones is the presence of downstep, and if we the Floating-L approach assumes from the outset that downstep is caused by floating tones, then we (and, perhaps more importantly, learners of the language) do not have independent evidence for the floating $L$ tones. But this argument is refutable in at least two ways. First, we showed above how downstep alternates with overt low tones at a single site within the word in Gã (and we will see that this is true of Tiriki as well); therefore, there is evidence from alternations for the floating $\mathrm{L}$ tones (or at least for $\mathrm{L}$ tones in the site where the Floating- $\mathrm{L}$ analysis would posit floating L tones). And second, downstep is not the only kind of phonological evidence that is available for the presence of floating tones; they can trigger or block phonological rules as well. For example, in Gã, perfective aspect is marked by a floating L tone prefix, which will cause a downstep when it occurs between a H-toned subject marker and a verb root with initial $\mathrm{H}$ tone (6).

$$
\begin{array}{ll}
\text { é-'lá } & \text { 'he has sung' } \\
\text { é-'dú } & \text { 'he has cultivated' } \\
\text { é-'wó } & \text { 'he has lifted' } \\
\text { é-'fó } & \text { 'he has wept' }
\end{array}
$$


When the same floating L tone prefix occurs between a H-toned subject marker and a verb root with an underlying / $\mathrm{LH} /$ tone pattern, the effect of the floating $\mathrm{L}$ is to block the rule described earlier, in which /HLH/ surfaces as $\mathrm{H}^{\prime} \mathrm{HH}$. The forms in (7) exhibit a surface HLH tone pattern because the input tone sequence, after affixation by the floating $\mathrm{L}$ prefix, is actually /H L' LH/ (where L' represents a floating L tone), which does not meet the structural description for the application of the rule.

$\begin{array}{ll}\text { é-hulú } & \text { 'he has jumped' } \\ \text { é-kojó } & \text { 'he has judged' } \\ \text { é-majá } & \text { 'he has sent' } \\ \text { é-basá } & \text { 'he has grabbed' }\end{array}$

Hence, in some languages the floating $\mathrm{L}$ tones in a Floating- $\mathrm{L}$ analysis can be independently motivated in a variety of different ways, and thus the analysis is not circular or even particularly abstract.

Because other ways of distinguishing the Floating-L vs. Separate-H analyses of downstep are not decisive, in this paper we will follow the approach taken by Gussenhoven (2004:104), who notes that the advantage of the Floating-L or Separate-H analysis for any particular language lies in the extent to which it unifies an otherwise disparate set of phonological facts. For example, a standard claimed advantage of the Floating-L is that it gives a unified representation to nonautomatic and automatic downstep. Non-automatic downstep, which is often simply called 'downstep,' is the lowering effect on a $\mathrm{H}$ tone following another $\mathrm{H}$ tone when no linked $\mathrm{L}$ tone intervenes. The 'non-automatic' part of the term refers to the fact that the lowering effect in this type of downstep does not follow from any phonological unit that is directly observable. On the other hand, automatic downstep, usually referred to as downdrift, is the phonetic lowering effect on a $\mathrm{H}$ tone with respect to a preceding $\mathrm{H}$ tone when a linked $\mathrm{L}$ tone intervenes. This phenomenon has been documented in many African languages, including Efik (Winston 1960), Akan (Schachter 1961), Twi (Schachter and Fromkin 1968), Hausa (Silverstein 1976, Inkelas and Leben 1991), Etsako (Elimelech 1978), Supyire (Carlson 1994), and Igbo (Hombert 1974, Laniran and Gerfen 1997). ${ }^{4}$

For the many languages displaying both downstep and downdrift, including Tiriki, the Floating-L representation has an immediately apparent advantage in that the lowering of the second $\mathrm{H}$ tone is directly related representationally to the lowering that applies to the second $\mathrm{H}$ in regular (linked) HLH sequences. Hence, both result from the phonetic component interpreting a single sequence, HLH (whether the L is linked to a tone-bearing unit or not), as lowering the pitch ceiling for the second $\mathrm{H}$. Downdrift or automatic downstep is represented as in (8), and its relationship to (5a) is clear: in each case, the $\mathrm{H}$ tone to the right of a phonological L tone is lower than the $\mathrm{H}$ to the left of the L. The pronunciation of downstep in this approach therefore requires the phonetic component to establish a new pitch ceiling for $\mathrm{H}$ tones after it encounters a $\mathrm{HL}$ sequence.

\footnotetext{
${ }^{4}$ We have pointed out the automatic vs. non-automatic downstep distinction because the terminology reflects the insight that downstep and downdrift are related phenomena. However, for the remainder of the paper our use of the term 'downstep' will refer to non-automatic downstep only.
} 


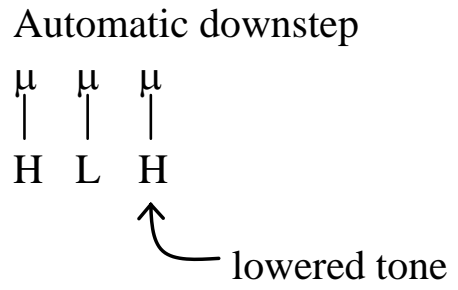

In contrast, the Separate-H analysis, unlike the Floating-L analysis, requires the phonetic component to interpret the second of two $\mathrm{H}$ tones in $(5 \mathrm{~b})$ as being lower than first $\mathrm{H}$ tone, and to separately lower a $\mathrm{H}$ tone after a $\mathrm{L}$ tone. Where the degree of phonetic lowering due to downstep and downdrift is phonetically equal, as is usually claimed in reports of languages with both downstep and downdrift, the Separate-H analysis treats the phonetic unity of the two processes as purely coincidental. Ideally, if the output of downstep and downdrift is phonetically identical, this should be reflected in their phonological analysis. ${ }^{5}$

In addition to capturing the relationship between downstep and downdrift, the Floating-L approach allows us to unify the phonological analysis of downstep in a language like Tiriki, where downsteps come from a variety of phonological sources. We will argue in favor of a Floating-L analysis of Tiriki downstep on the basis that there is an exact one-to-one correspondence in the language between the sites where the presence of a phonological floating L tone is independently predicted, and the sites where phonetic downstep is empirically attested. This is a striking fact about Tiriki that is not true of other languages such as Kikuyu, where in some cases a floating $\mathrm{L}$ tone is posited to account for a downstep in a given location in the word/phrase, based on evidence from elsewhere in the language that floating L tones cause downstep, even though there is no direct evidence for a $L$ tone at that exact location. Thus, Tiriki is an important language to consider in comparing the Separate-H vs. Floating- $\mathrm{L}$ approaches to downstep. For many languages the two approaches are equivalent in their empirical adequacy and explanatory value, but we will argue that this is not the case in Tiriki.

\section{Downstep in Tiriki}

Having considered some aspects of the phonological representation of downstep, we move on to the analysis of Tiriki. This section has two purposes. The first is to give an overview of the tonal phonology of Tiriki, which has not previously been described in the linguistic literature. The second is to show the advantages of a Floating- $\mathrm{L}$ analysis over a Separate- $\mathrm{H}$ analysis for downstep in this particular language. Tiriki presents a unique case study because floating L tones in the downstep contexts are independently motivated, yet in most cases these L tones are crucially absent from the underlying representation (since there is a contrast between underlyingly prespecified L tone and $\varnothing$ ). We thus account for most instances of downstep via the same $\mathrm{L}$ tone insertion process that is also responsible for default $\mathrm{L}$ tones in the language. We will argue that this process is part of the regular phonology of the language (i.e., it does not reduce to phonetic interpretation) and interacts accordingly with other phonological processes.

\footnotetext{
${ }^{5}$ There do exist languages, e.g., Bamileke-Dschang (Hyman 1985) and Kikuyu (Clements and Ford 1979), that exhibit downstep but not downdrift. This fact is immaterial to the choice between the Separate-H vs. Floating-L analyses since it is compatible with either model. Under the Floating-L model, in these languages the phonetic component would simply have to be able to interpret a sequence of linked-L plus $\mathrm{H}$ differently from a sequence of floating-L plus H. This seems reasonable since there is a structural phonological difference to be exploited.
} 


\subsection{Basics of Tiriki tonology}

Tiriki is a Bantu language of the Luyia subgroup (J30) spoken in Western Kenya. All forms cited are from a male consultant, a native of Hamisi, Kenya. In our analysis, the tone-bearing unit (TBU) is the mora, and tones are (in general) underlyingly linked to TBUs. Tiriki has an underlying contrast between $\mathrm{H}$-toned and toneless moras, and in addition, there is evidence that some moras have underlying $\mathrm{L}$ tones, ${ }^{6}$ since these moras behave differently from the toneless moras. L-toned moras always surface with $\mathrm{L}$ tone, while toneless moras surface with $\mathrm{L}$ tone except in certain contexts where they become $\mathrm{H}$. We can thus say that Tiriki has a three-way underlying contrast between $\mathrm{H}$, toneless, and $\mathrm{L}$ that reduces to a two-way surface contrast between $\mathrm{H}$ and $\mathrm{L}$ (plus downstepped $\mathrm{H}$ ).

In this subsection, we give a brief introduction to basic tone patterns in Tiriki. In $\$ 3.2$, we further explore the details of the tone system as needed to explain downstep and present a full analysis of the tone system.

We begin by establishing the difference between $\mathrm{H}$-toned and toneless verbs. Examples of each are shown in (9) in the infinitive, which reflects the underlying verb root tones. Vowels with underlying $\mathrm{H}$ tones are underlined.

$\begin{array}{ll}\text { H-toned verbs } & \\ \text { xú-rhúmul-a } & \text { 'to hit' }{ }^{7} \\ \text { xú-xárag-a } & \text { 'to cut' }\end{array}$

Toneless verbs

xu-molom-a 'to speak'

xu-gul-a 'to sell'

Note that the $\mathrm{H}$-toned verbs have surface $\mathrm{H}$ tones on both the verb root and the prefix; this will be explained via a $\mathrm{H}$ Tone Anticipation rule to be introduced later in this section.

The first tone rule to be discussed is Meeussen's Rule, schematized in (10). When there are two $\mathrm{H}$ tones on adjacent TBUs, the second $\mathrm{H}$ becomes an $\mathrm{L}$ tone.

Meeussen's Rule<smiles>[TlH]</smiles>

Examples showing Meeussen's Rule are seen below. For example, when a H-toned object prefix or tense prefix attaches to a H-initial verb, the verb-initial mora becomes L-toned, as shown in (11a-b). Surface $\mathrm{H}$ tone is marked by an acute accent, while $\mathrm{L}$ tone is not marked, and an underlined vowel indicates the assumed underlying location of a $\mathrm{H}$-tone. A grave accent

\footnotetext{
${ }^{6}$ There is a possible alternative analysis, independently suggested to us by Lee Bickmore and Larry Hyman, using underlying $\mathrm{H}$ tones only. It can be observed that all instances of surface non-alternating $\mathrm{L}$ tone, which we treat by prespecification, appear in conjunction with a preceding $\mathrm{H}$ tone. For example, in và-rháánô 'five (cl. 2)' the prefix carries a floating $\mathrm{H}$ tone which docks onto the previous word. This raises the possibility that Meeussen's Rule applies at an early stage between the first, floating $\mathrm{H}$ tone and a $\mathrm{H}$ tone that is linked to the prefix, causing the linked $\mathrm{H}$ to change to L. However, we argue that because these morphemes invariably surface with $\mathrm{L}$ tones, learners will posit pre-specified $\mathrm{L}$ tones rather than considerably more abstract representations with $\mathrm{H}$ tones that are never realized overtly in any surface form. Under either analysis, phonologically specified L tones must already be present at the stage when default $\mathrm{L}$ tones are assigned.

${ }^{7}$ Orthographic $\langle x>$ represents a voiceless velar fricative, and $<$ rh $>$ represents a voiceless apical trill.
} 
indicates a TBU with underlying or Meeussen's Rule-induced (i.e. non-default) L tone. A vowel with both underlining and a grave accent therefore indicates an underlying $\mathrm{H}$ tone that has been converted to a L tone by Meeussen's Rule, whereas a non-underlined vowel with a grave accent has a non-alternating $\mathrm{L}$ tone.

(11a) H-toned object prefix $+\mathrm{H}$-initial verb

xú-múu-rhùmul-il-a 'to hit for him'

xú-múu-rhùm-a 'to send him/her'

y-á-gá-rhùm-a 'he sent it (cl. 5; general past)'

(11b) H-toned tense prefix $+\mathrm{H}$-initial verb

v-áá-rhùmul-il-an-a 'they have hit for each other before (experiential)'

y-áá-xârag-a zi-nguza 'he has cut vegetables before'

Similarly, when a H-toned tense prefix is followed by a H-toned object prefix, the object prefix gets a L tone in the surface form, as in (12).
y-áá-gàn-gul-iz-a 'he has sold it (cl. 5) before'
y-áá-mù-molom-el-a 'he has spoken for him/her before'

A final context for Meeussen's Rule is when a function word with $\mathrm{H}$ tone precedes a noun with a H-toned prefix, as in (13a) ((13b) shows the same nouns in isolation to give evidence for underlying $\mathrm{H}$ tones on their prefixes).
(13a) ní zì-ngúvùu 'with hippos'
ní lì-dúúmà 'with corn (sg.)'
lú-límì lú ì-síímbwà $\quad$ 'tongue of a dog'
mw-óóyò gú ì-síímbwà 'heart of a dog'
zí-'ngúvù
'hippos'
lí-'dúúmà
1́-'síímbwà
'corn (sg.)'
'dog'

As seen in the examples below, when there are separate $H$ tones associated to three adjacent moras in the input, the result is that the second of the three moras gets L tone.

$$
\begin{array}{ll}
\text { v-áá-rhùmul-il-an-a } & \text { 'they have hit for each other before (experiential)' } \\
\text { v-áá-mù-rhúmul-il-a } & \text { 'they have hit for him before (experiential)' } \\
\text { y-áá-gạ-lị́iz-a } & \text { 'he has fed it (cl. 5) before (experiential)' }
\end{array}
$$

This can be accounted for if we assume that Meeussen's Rule applies to leftmost possible context, so that in a sequence of $\mathrm{H}+\mathrm{H}+\mathrm{H}$, it is the second $\mathrm{H}$ tone that undergoes Meeussen's Rule.

Another tone rule in Tiriki is High Tone Anticipation (HTA). Evidence for HTA comes from the behavior of noun class prefixes, which surface as L-toned before toneless roots (15a), and $\mathrm{H}$ toned before roots with initial $\mathrm{H}$ (15b). 


\begin{tabular}{|c|c|c|c|c|}
\hline $\begin{array}{l}\text { mu-undu } \\
\text { mu-limi }\end{array}$ & $\begin{array}{l}\text { 'person' } \\
\text { 'farmer' }\end{array}$ & $\begin{array}{l}\text { va-andu } \\
\text { va-limi }\end{array}$ & $\begin{array}{l}\text { 'people' } \\
\text { 'farmers' }\end{array}$ & $\begin{array}{l}\text { mu-saaliisi 'priest' } \\
\text { mu-gulizi 'salesperson' }\end{array}$ \\
\hline & 'wife' & vá-xálì & 'wives' & \\
\hline mú-lína & 'friend' & vá-lína & 'friends' & \\
\hline
\end{tabular}

So far we have shown evidence only for a $\mathrm{H}$ tone being anticipated on one mora immediately preceding the mora that underlyingly bears the $\mathrm{H}$. In fact, HTA is unbounded, so that a $\mathrm{H}$ tone can be linked to any number of moras to the left of the mora that underlyingly bears it. This means that in general, there are no $[\mathrm{LH}]$ sequences within phrases unless the $\mathrm{L}$ is prespecified or derived via Meeussen's Rule. Below are some examples demonstrating unbounded HTA in various types of phrases. ${ }^{8}$

(16a) Noun + Adjective

$\begin{array}{llll}\text { mu-limi } & \text { 'farmer’ } & \text { i-nyama } & \text { 'meat' } \\ \text { mú-límí mú-láhi } & \text { 'good farmer' } & \text { ínyámá í-mbịsi } & \text { 'raw meat' } \\ \text { mu-undu } & \text { 'person' } & \text { zi-nguvu } & \text { 'clothes' } \\ \text { mú-úndú mú-néne } & \text { 'big person' } & \text { zí-ngúvú zí-ndávu } & \text { 'white clothes' }\end{array}$

(16b) Noun (Subject) + Verb

mú-límí y-á-lya $\quad$ 'the farmer ate' (general past)

vá-límí ví-1́luxaaj-e 'the farmers have just run’

(16c) Verb + Noun (Object)

xu-molom-el-a mu-limi 'to speak for a farmer'

xú-mólóm-él-á mú-lína 'to speak for a friend'

Example (17) shows that the $\mathrm{H}$ tone that spreads via HTA can come not only from a stem (as has been the case in the preceding examples), but also from other elements, such as prefixes.
xu-molom-el-a
'to speak for'
xú-múu-molom-el-a
'to speak for him/her'

Based on its properties described above, the HTA rule is schematized below in (18). The circled mora indicates that the mora is not linked to a tone.

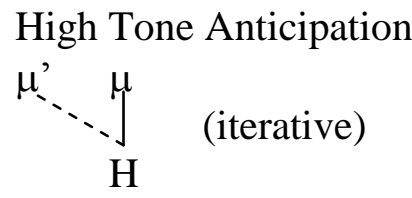

When the $\mathrm{H}$ tone is preceded in the phrase by a prespecified $\mathrm{L}$ tone, it will fail to reach the left end of the phrase. In this situation, HTA is 'stopped' by the $\mathrm{L}$, so that the $\mathrm{H}$ tone will be realized

\footnotetext{
${ }^{8}$ Truly "unbounded" HTA appears to be a rare phenomenon, attested to our knowledge only in the closely related language Llogoori (Marlo and Odden 2005). But see Kaplan 2008 for arguments that non-iterativity in phonological rules is an emergent property.
} 
as far to the left as it can go until it reaches the L. We indicate this by specifying that the rule applies only to toneless moras, so that if the mora is already linked to a tone, a $\mathrm{H}$ will not be spread onto that mora via HTA.

Some examples showing HTA stopped by prespecified L tones from various sources are shown in (19a-d) below (a linked L tone, whether underlying or derived, is marked by a grave accent).

(19a) Prespecified L tone on subject agreement prefix và-lixa-molom-el-e mu-limi 'they will speak for a farmer (distant future)' và-líxá-mólóm-él-é mú-lína 'they will speak for a friend (distant future)'

(19b) Prespecified L tone on recent past prefix và-à-molom-eel-e mu-limi 'they have just spoken for a farmer' và-à-mólóm-éél-é mú-lína 'they have just spoken for a friend'

(19c) Prespecified L tone on persistive prefix và-shì-molom-el-a-a mu-limi 'they speak for a farmer (persistive)' và-shì-mólóm-él-á-á mú-lína 'they speak for a friend (persistive)'

(19d) Prespecified L tone on suffixes và-mólóm-eel-è mú-lína 'they spoke for a friend (hodiernal perfective)' v-á-mólom-el-à mú-lína 'they spoke for a friend (general past)' v-á-mólom-el-à-à mú-lína 'they used to speak for a friend (past habitual)' na-và-mólóm-él-è mú-lína 'they will speak for a friend (crastinal future)'

HTA will also not spread a $\mathrm{H}$ onto a mora already bearing a $\mathrm{H}$ tone. This will be demonstrated in the following section when we present contexts for downstep.

Importantly, a L tone created by Meeussen's Rule blocks HTA, just like other prespecified L tones. This is why Meeussen's Rule must be formulated to change the second of two H tones into a L tone, rather than deleting it. ${ }^{9}$ As shown below in (20), in a case where an underlying $\mathrm{HH}$ sequence is followed by one or more toneless moras and another $\mathrm{H}$ toned mora, the result is HLH.
xú-múu-rhümúl-íl-á mú-lína
'to hit him/her for a friend'
y-áá-xăág-á mínáázi
'he has cut coconuts before'
y-áá-mü-mólóm-él-á vúduxu
'he has spoken for him before at night'

A third tone rule is Final Lowering, which is an exceptionless rule where a phrase-final H-toned mora is delinked from its $\mathrm{H}$ tone. Our rule of Final Lowering is shown in (21).

\footnotetext{
${ }^{9}$ An alternative explanation is that HTA is blocked by the second H, which is later deleted by Meeussen's Rule and surfaces as L via Low Tone Insertion (thanks to Dave Odden for pointing this out). This alternative is incompatible with our Floating-L account because Low Tone Insertion applies before HTA (this is crucial to our analysis of downstep). If Meeussen's Rule had to apply after HTA, then in order to avoid an ordering paradox, we would have to stipulate that Low Tone Insertion applies a second time immediately before Low Tone Linking.
} 


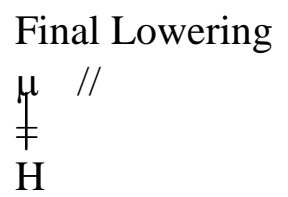

Because Final Lowering is exceptionless (i.e., the lack of phrase-final $\mathrm{H}$ tones is a surface-true generalization in Tiriki), we assume that there is a (floating) L boundary tone at the end of each phrase. Final Lowering is ordered after HTA, since an underlying final $\mathrm{H}$ will spread before delinking from the final mora, as in the word mú-rhwì 'head', which surfaces as HL in citation form despite having a toneless prefix and $\mathrm{H}$ tone root underlyingly.

\subsection{A Floating-L analysis of downstep in Tiriki}

The contexts for downstep in Tiriki can be generalized as follows: downstep occurs between $\mathrm{H}$ tones on surface-adjacent moras that were separated at some stage by one or more underlyingly toneless moras. In the examples to follow, we show the various different ways in which this generalization is manifested.

The first way in which $\mathrm{H}$ tones come together, sometimes resulting in downstep, is via High Tone Anticipation (HTA). One context in which a $\mathrm{H}$ tone fails to be manifested at the left edge of a phrase is when another $\mathrm{H}$ tone intervenes between the $\mathrm{H}$ and the left edge. In this case, the second $\mathrm{H}$ is anticipated leftward until it reaches the first $\mathrm{H}$, and the second $\mathrm{H}$ is downstepped. Thus, this is the environment in which HTA leads to downstep. Examples are shown in (22a-c) (downstep is indicated by an exclamation mark).

(22a) $\mathrm{H}$ tone from an object spreads leftward to meet $\mathrm{H}$ tone from a prefix $\mathrm{v}$-áá-molom-el-a mu-limi 'they have spoken for a farmer before' $\mathrm{v}$-áá-'mólóm-él-á mú-lína 'they have spoken for a friend before' và-à-mú-molom-eel-e mu-limi 'they have just spoken for a farmer' và-à-múu-'mólóm-éél-é mú-lína 'they have just spoken for a friend'

(22b) $\mathrm{H}$ tone from an object spreads leftward to meet $\mathrm{H}$ tone from a verb và-mù-rhúmulil-a-a mu-limi 'they are hitting for a farmer' và-mù-rhú 'múlíl-á-á mú-lína 'they are hitting for a friend'

(22c) $\mathrm{H}$ tone from a verb spreads leftward to meet $\mathrm{H}$ tone from a prefix và-à-múu-molom-eel-e v-á-múu-'mólómel-a 'they have just spoken for him/her' 'they spoke for him/her'

Parallel to the examples above in (19) where a L tone blocks HTA, the failure of HTA to spread through a preceding linked $\mathrm{H}$ tone is captured by our statement of the rule, since a $\mathrm{H}$ will not be anticipated onto a mora that already bears a tone, and it will not be anticipated onto a toneless mora across a tone-bearing mora due to the No Line Crossing constraint.

Our analysis of downstep is based on the important fact that underlyingly toneless moras become L-toned by a default $\mathrm{L}$ tone assignment rule when they do not get a tone via some other rule. This is seen in several examples above, such as xu-molom-el-a 'to speak for', where no mora underlyingly bears a $\mathrm{H}$ tone, so the entire phrase surfaces as L-toned. In our analysis, this 
default L tone assignment takes place in two steps: insertion of one L tone for every toneless mora, followed by linking of floating $L$ tones to toneless moras. While not crucial to a form in which all TBUs surface with $L$ tone, the separation of the insertion and linking processes is necessary to account for the behavior of downstep, as we will see, since no phonological rule in Tiriki causes a linked tone to become a floating tone. The rules of $\mathrm{L}$ tone insertion and linking are schematized in (23a) and (23b), respectively.

(23a) Low Tone Insertion

$\mu$

$\mathrm{L} \leftarrow \varnothing$

(23b) Low Tone Linking

$\mu_{1}$

i's

$\mathrm{L}$

The fact that we have analyzed Low Tone Insertion as a full-fledged phonological process rather than a phonetic one is not trivial. It is required by our view of the phonetic interpretation component, since in our view phonetic interpretation cannot include any processes that neutralize distinct phonological representations. ${ }^{10}$ By locating Low Tone Insertion in the phonology, we predict that default $\mathrm{L}$ tone insertion should behave like any other phonological rule. The $\mathrm{L}$ tones that are inserted via this process should behave as if they are real, phonological L tones, and the Low Tone Insertion rule should be orderable with respect to other phonological rules rather than simply applying at the end of the derivation. We also predict that in some language, the Low Tone Insertion could be ordered earlier than in Tiriki, so that $\mathrm{H}$ tones that come together via certain early rules do not get a downstep between them, while $\mathrm{H}$ tones that come together via other, later rules do trigger downstep. As we will see later in this section and in $\S 4$, both of these predictions are upheld, in Tiriki and elsewhere.

Below is a sample derivation using the form vàà-mú-'mólóm-éél-é mú-lína 'they have just spoken for a friend' to show the crucial ordering of Low Tone Insertion, High Tone Anticipation, and Low Tone Linking. ${ }^{11}$

\footnotetext{
${ }^{10}$ One could get around this by assuming that there is never a phonological $\mathrm{L}$ tone in the representation of a form that surfaces with a default $\mathrm{L}$ tone, and thus the phonetics would not have to insert a $\mathrm{L}$ tone, but this introduces the question of how the phonetic component knows to interpret something without any tone as being pronounced at the same pitch level as something specified as L. Without phonological Low Tone Insertion, and assuming that phonetics cannot insert a phonological tonal specification, the identical surface realization of phonologically toneless and phonologically L-toned forms would be purely coincidental. In our view, this is not coincidental but rather the straightforward result of Low Tone Insertion. An alternative claim would be that default L tones are phonetically underspecified, such that the pitch simply "sags" between H tones (cf. Myers 1998). We reject this possibility for Tiriki because in phrases where a $\mathrm{H}$ tone is followed by a sequence of L-toned syllables extending to the end of the phrase (e.g., và-mù-rhúmulil-a-a mu-limi 'they are hitting for a farmer'), a "sagging pitch" approach would predict that the pitch should decline gradually from the $\mathrm{H}$ to the phrase-final $\mathrm{L}$. But in fact, in such examples, the pitch drops sharply on the first L-toned syllable after the $\mathrm{H}$ (and then continues on a slight, gradual decline from this already low level through the end of the phrase), which is more consistent with the claim that the L tones are specified.

${ }^{11}$ In this and other sample derivations to follow, we show only a single $\mathrm{L}$ tone being inserted for a continuous sequence of toneless moras. It is possible that the insertion analysis should be implemented by inserting one $\mathrm{L}$ tone
} 


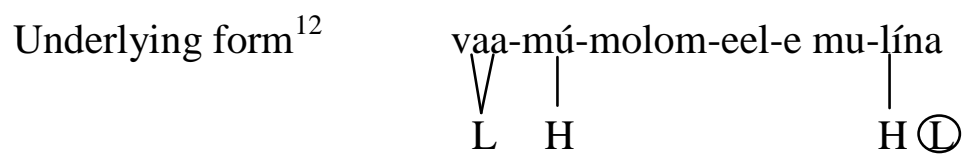

Low Tone Insertion

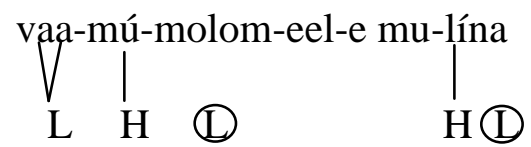

High Tone Anticipation

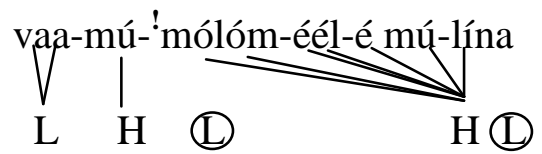

Low Tone Linking

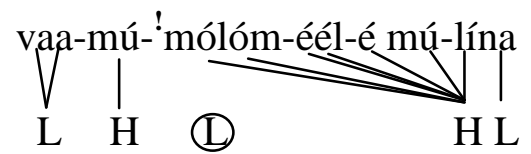

The contrast between underlyingly L-toned and toneless TBUs is illustrated by words like múxálì 'wife', with a L-toned final vowel, and mú-lína 'friend', with a toneless final vowel. In HTA contexts, a H tone will spread onto the toneless final vowel of mú-lína, as in (25). The floating L licensed by that vowel gives rise to a downstep. However, the L-toned final vowel of mú-xálì blocks spreading just like other linked Ls, as shown in (25), and no downstep results.
mú-lí!ná mú-gálì
'big friend'
mu-xálì mú-gálì̀
'big wife'

In non-HTA contexts, such as in isolation, the words are tonally identical because the floating $\mathrm{L}$ will link to the final vowel of mú-lína at a late stage of the derivation.

Based on our analysis so far, two specific predictions are made about downstep in Tiriki. The first is that phonological processes other than HTA that result in input non-adjacent $\mathrm{H}$ tones becoming adjacent in the output should cause downstep just like HTA, because the toneless moras that intervene between $\mathrm{H}$ tones underlyingly should project a $\mathrm{L}$ tone that will result in downstep. The second is that sequences of $\mathrm{H}$ tones that come together through some other, nonphonological operation should not have a downstep inserted between them (unlike in languages such as Supyire (Carlson 1994) and Shambaa (Odden 1986) in which downstep occurs between all sequences of adjacent $\mathrm{H}$ tones regardless of how they came to be adjacent). This is because the $\mathrm{L}$ tone that causes downstep in Tiriki is not inserted in every $\mathrm{H}+\mathrm{H}$ environment, but only when one or more underlyingly toneless moras are present between the $\mathrm{H}$ tones in the underlying form. As we will see in this section, both of these predictions are correct.

for each mora within the sequence; this might then entail a late rule reducing sequences of adjacent floating $\mathrm{L}$ tones to a single floating $\mathrm{L}$ by erasing any floating $\mathrm{L}$ tone that occurs immediately to the right of another $\mathrm{L}$ tone. In any case, our sample derivations reflect a single L tone for the sequence, for the purposes of a cleaner visual display of the derivations.

${ }^{12}$ This and representations to follow will include a floating L boundary tone (discussed above) at the right edge of the phrase. 
Our first prediction is that phonological processes other than HTA result in downstep whenever they cause $\mathrm{H}$ tones that were not adjacent in the input to become adjacent in the output. This is confirmed by examples in which a floating $\mathrm{H}$ tone is associated to an underlyingly toneless mora next to a H-toned mora, as shown below.

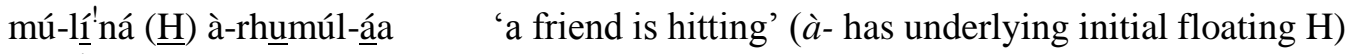

$$
\begin{aligned}
& \text { vá-lílná }(\underline{H}) \text { và-gwíiz-aa 'friends are falling' (và- has underlying initial floating } H \text { ) } \\
& \text { vá-lílná }(\underline{\mathrm{H}}) \text { và-rháánô } \quad \text { 'five friends' (và-rháánô has underlying initial floating } \mathrm{H} \text { ) } \\
& \text { vá-línà vá-á-'njé }(\underline{H}) \text { va-àndî } \quad \text { 'my other friends' (va-àndî has underlying initial floating } \mathrm{H} \text { ) }
\end{aligned}
$$

The floating $\mathrm{H}$ tone is associated to the toneless mora via High Tone Linking (27).

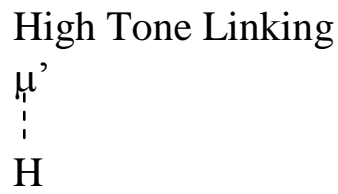

This rule is ordered before Low Tone Linking, which explains why the $H$ tone, rather than the preceding L tone, is associated to the free mora in these examples. High Tone Linking also must be ordered after Low Tone Insertion (since a L tone is inserted for every sequence of underlyingly toneless moras, even those that end up being associated to a $\mathrm{H}$ tone) but before High Tone Anticipation (since our anticipation rule spreads a $\mathrm{H}$ that is already linked to a mora).

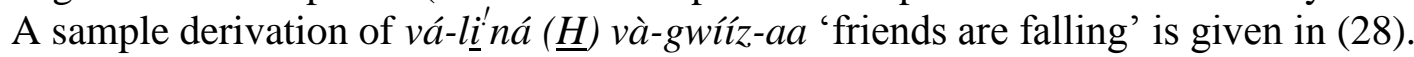

(28) Underlying form

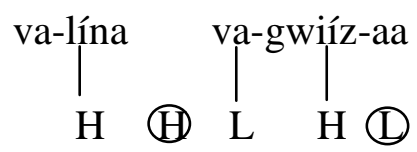

Low Tone Insertion

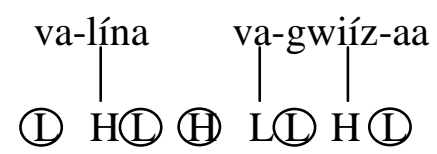

High Tone Linking

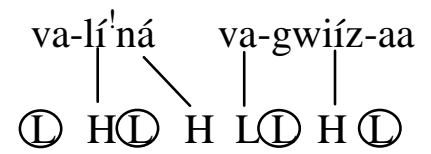

High Tone Anticipation

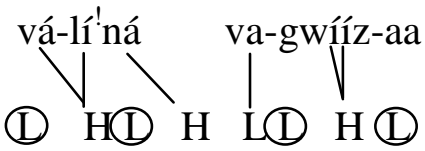

Low Tone Linking

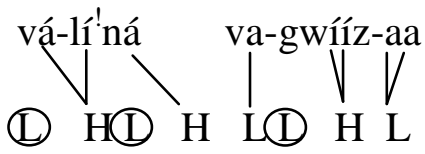

We also find confirmation of our prediction in examples where a toneless mora between two $\mathrm{H}-$ toned moras is lost via glide formation (29a-b) or vowel coalescence (29c). As seen in the 
examples below, when this happens, the toneless mora still results in a surface L tone even though the mora is absent in the surface form. This is captured in our analysis by the fact that Low Tone Insertion applies prior to glide formation and vowel coalescence.

(29a) Glide formation moves a lexical tone one mora to the right
/xu-li-a li-duuma/
$\rightarrow$ xú-lyá ! lí 'dúúmà
'to eat corn'

(29b) Glide formation removes intervening mora between two $\mathrm{H}$ tones

/mu-rhwị gu-ü mu-linna/ $\rightarrow$ mú-rhwí ! gwú 'mú-lína 'head of a friend'

/mu-rhwi gu-âa-nje/ $\rightarrow$ mú-rhwí 'gw-áa-nje $\quad$ 'my head'

(29c) Vowel coalescence removes intervening TBU between two $\mathrm{H}$ tones

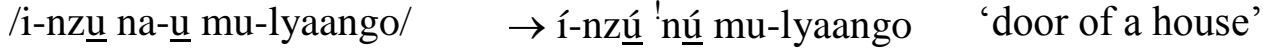

Note that the example xú-lyá 'lị́ dúúmà (29a) exhibits Final Lowering.

A second prediction of our analysis is that when $\mathrm{H}$ tones come together by concatenation within the morphology or syntax, no downstep is observed. In most environments, the second of two $\mathrm{H}$ tones that become adjacent through a non-phonological operation is changed to $\mathrm{L}$ via Meeussen's Rule. However, there are some instances in which Meeussen's Rule does not apply, and in these limited contexts where we are able to find evidence bearing on our prediction, the prediction does seem to be correct.

For example, Meeussen's Rule does not apply across word boundaries, except in the case of some function words. Therefore, when the syntax causes a $\mathrm{H}$-final word to be adjacent to a $\mathrm{H}$ initial word, the second $\mathrm{H}$ is not downstepped, but rather is pronounced at the same level as the first $\mathrm{H}$ tones. ${ }^{13}$ Examples of this are shown in (30). ${ }^{14}$

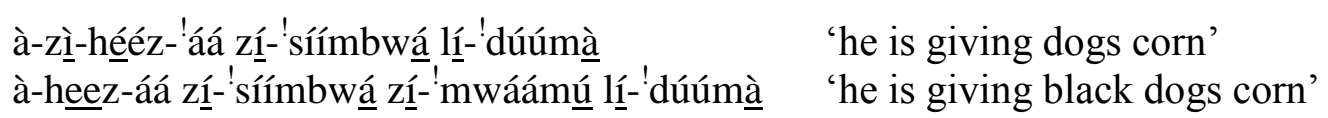

(31) shows a location where two $\mathrm{H}$ tones come together via syntax, and no $\mathrm{L}$ tone is inserted between the adjacent $\mathrm{H}$ tones since no toneless mora intervened between them underlyingly.

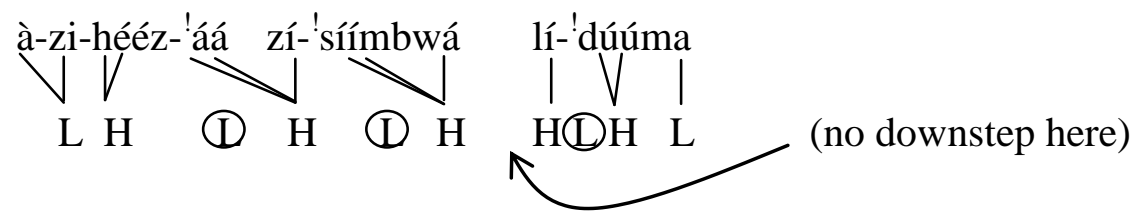

\footnotetext{
${ }^{13}$ In some cases, there seemed to be a slight pitch drop between these $\mathrm{H}$ tones. For every case where we perceived a pitch drop, our consultant also produced the same construction without a pitch drop and found no distinction (in fact, said he heard no difference) between non-downstepped and downstepped variants as produced by us. This is in opposition to the fact that he always confidently rejected non-downstepped variants produced by us in places where there should have been downstep, even in multi-downstep sequences with multiple finer-grained pitch levels. We believe that his acceptance of slight pitch drops in this one specific context reflects sentence-level intonational declination rather than phonological tonal downstep.

${ }^{14}$ These examples exhibit a phenomenon where input $\mathrm{L}+\mathrm{H}$ surfaces as LL; this accounts for the surface $\mathrm{L}$ tones on [zi] and [heez] in 'he is giving dogs corn' and 'he is giving black dogs corn', respectively. We do not discuss this rule in further detail since it is not fully regular and does not bear on the rest of our analysis.
} 
One may attempt to explain the variation in (31) by appealing to some limit in the phonology on the number of successive downsteps in an utterance. Alternatively, one might hypothesize that there really would be a downstep before lí-'dúumà in (31), but the lowering is obscured by an opposite phonetic effect that raises lí before a downstep. However, such explanations are countered by examples such as the one in (32), which shows multiple successive downsteps in an utterance.

$$
\text { zí-'ngúvú 'zy-ú 'mú-línà 'friend’s hippos' }
$$

There is a second context in which it appears that $\mathrm{H}$ tones come together without triggering Meeussen's Rule, this time in the morphology rather than syntax. There are some tenses/aspects in Tiriki (e.g., the middle future and subjunctive in affirmative main clauses) which exhibit a tonal pattern that we refer to as " $\mathrm{H} 2 \mathrm{H}+\mathrm{L}$ ". This means that the tense/aspect assigns a $\mathrm{H}$ tone to the second mora of the verb (not counting prefixes) and a $\mathrm{H}$ tone to everything that follows the second mora up to the final vowel of the verb, which gets a L tone. Below are toneless verbs in the subjunctive (these are followed by toneless objects so that the tone of the verbs' final vowels will not be obscured by Final Lowering).

$$
\begin{array}{ll}
\text { ù-lól-é mù-lìmì } & \text { 'see a farmer (subj.)' } \\
\text { ù-jííng-é mù-lìmì } & \text { 'carry a farmer (subj.)' } \\
\text { và-mólóm-él-è mù-lìmì } & \text { 'they speak for a farmer (subj.)' }
\end{array}
$$

The reason that we analyze this as " $\mathrm{H} 2 \mathrm{H}+\mathrm{L}$ " rather than, e.g., "Penult $\mathrm{H}+\mathrm{L}$ " is that, as can be seen by comparing ù-jílg-é mùlìmì with và-mólómél-è mùlìmì, the $\mathrm{L}$ tone will associate to the final vowel only if it is preceded in the verb by at least three moras. Given this, it may be tempting to characterize the subjunctive tone pattern as " $\mathrm{H} 3+\mathrm{L}$ " (i.e., $\mathrm{H}$ tone on the third mora and L tone on the final vowel), but "H3" fails for two reasons. First, the $\mathrm{H}$ tone of the subjunctive will associate to the second mora of a verb that has only two moras (as in $\grave{u}$-lól-é mùlimi above); "H3" would predict that the H should not associate to the verb unless it had at least three moras. And second, when the verb has more than four moras, all moras up to the final vowel still get a $\mathrm{H}$ tone, as in và-mólóm-él-án-è 'they speak for each other (subj.)'. If we characterized the pattern as "H3+L", then we would incorrectly predict that the verb 'they speak for each other (subj.)' should surface as *và-mólóm-él-àn-è.

We therefore analyze the subjunctive as assigning multiple $\mathrm{H}$ tones: one to the second mora of the verb (i.e., "H2") and a $\mathrm{H}$ tone for each mora that follows it in the verb ${ }^{15}$ until the final vowel. This can be stated via the following rules (note that \# is used here to refer to the boundary between the verb prefixes and stem):

\footnotetext{
${ }^{15}$ The reason that we assume there are multiple $\mathrm{H}$ tones following $\mathrm{H} 2$, rather than one $\mathrm{H}$ tone that spreads, is that there is no good way to make the spreading work in long verbs. If we assigned $\mathrm{H}$ to the third mora, we would have to posit a rightward $\mathrm{H}$ spreading rule which is otherwise unattested in Tiriki. And we cannot assign $\mathrm{H}$ to the penultimate mora and assume that it spreads leftward via HTA, because "penultimate mora" is inaccurate, as demonstrated in trimoraic verbs such as ù-jííg-é mù-lìmì in which $\mathrm{H}$ is assigned to the final mora.
} 
Subjunctive Tone Assignment

1. $\# \mu \begin{aligned} & \mu \\ & \vdots \\ & \end{aligned}$

2. $\begin{array}{llllll}\mu & \mu & \mu & \mu_{1} & \text { verb } \\ \vdots & \\ & & L & \leftarrow \varnothing\end{array}$

3.

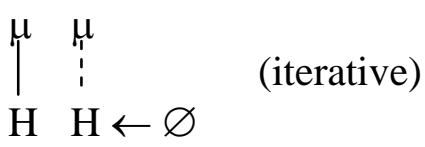

If this is indeed the correct analysis of tone in subjunctive verbs, then this constitutes an instance in which $\mathrm{H}$ tones come together without triggering Meeussen's Rule. And as seen in the examples in (33), when these $\mathrm{H}$ tones come together, no downstep occurs between them. This is consistent with our prediction that a downstep will occur only between surface-adjacent $\mathrm{H}$ tones that were non-adjacent at some stage in the derivation. ${ }^{16}$

Our analysis of downstep as being caused by floating $L$ tones posits a relationship between the phonologically derived downstep described above and another type of downstep, which is the grammatically conditioned downstep that marks some tense/aspect/mood categories. Grammatically conditioned downstep lends itself to an analysis in terms of floating L tones since in some contexts it is realized overtly as a linked L tone, as will be seen below. Analyzing all downsteps, not just grammatically conditioned ones, as being caused by floating L tones between $\mathrm{H}$ tones allows for a unified account for all instances of downstep in Tiriki regardless of their source.

Grammatically conditioned downstep occurs anytime a grammatically assigned L tone does not have enough 'room' to be linked to a mora. This can be seen in the subjunctive, which has the "H2H+L" pattern described above. The examples in (35) have verbs that are long enough to support the full $\mathrm{H} 2 \mathrm{H}+\mathrm{L}$ pattern; i.e., there are four moras in the verb (not counting the prefixes),

\footnotetext{
${ }^{16} \mathrm{An}$ anonymous reviewer has suggested an alternative analysis of the subjunctive that minimizes or eliminates adjacent $\mathrm{H}$ tones. In the alternative analysis, the three steps in the formation of the subjunctive are as follows: First, assign a $\mathrm{L}$ tone to a toneless final mora of any verb with four or more moras. Second, assign a $\mathrm{H}$ tone to a toneless final mora of any verb regardless of its size (thereby assigning final $\mathrm{H}$ to verbs that did not receive a final $\mathrm{L}$ tone in the previous step). Finally, assign a $\mathrm{H}$ tone to the penultimate mora of the verb; this $\mathrm{H}$ will then spread via HTA, yielding the correct surface forms. Under this reanalysis, the only adjacent $\mathrm{H}$ tones would be the penult $\mathrm{H}$ and the final $\mathrm{H}$, in forms with 3 or fewer moras. This would mean that the subjunctive provides a much less robust context for testing the prediction that downsteps will not occur between underlyingly adjacent $\mathrm{H}$ tones. Even these adjacent $\mathrm{Hs}$ can be eliminated if step 3 assigns $\mathrm{H}$ to the penultimate mora only when the final mora has a $\mathrm{L}$ tone. One problem with this proposed reanalysis is its incompatibility with examples such as và-mù-mólóm-èl-è 'they speak for him (subj.)', in which the presence of the object marker mù- triggers a slightly different tone pattern on the verb, which we refer to as "H2L". In our analysis, the H2L pattern would result from the application of the first and second subjunctive tone rules in (34), but not the third rule. Thus, the $\mathrm{H} 2 \mathrm{H}+\mathrm{L}$ and $\mathrm{H} 2 \mathrm{~L}$ patterns are related to each other in the analysis. Under the alternative analysis, "H2L" examples like và-mù-mólóm-èl-è would have to receive a completely different analysis from the one used for their counterparts that lack the object marker. The H2L examples would not undergo the rule assigning a $\mathrm{H}$ to the penultimate syllable, and instead a new rule would have to be proposed that would assign a $\mathrm{H}$ to the second syllable.
} 
so the "H2" tone associates to the second mora and spreads leftwards, the $\mathrm{H}$ tone associates to the third mora, and the L associates to the final vowel.

$$
\begin{array}{ll}
\text { ù-mólóm-él-è zí-'síímbwà } & \text { 'speak for the dogs (subj.)' } \\
\text { ù-rhúmúl-1́l-è zí-'símbwà } & \text { 'hit for the dogs (subj.)' }
\end{array}
$$

(36) demonstrates how the grammatical tones of the subjunctive are associated straightforwardly to a verb with four moras (not including the subject agreement prefix). The " $\mathrm{H} 2$ " $\mathrm{H}$ tone is anticipated via HTA just like the underlying final $\mathrm{H}$ of the object noun $z \underline{i} \underline{i}^{\prime}$ símbwà (note that this final $\mathrm{H}$ is delinked due to the Final Lowering phenomenon mentioned earlier).

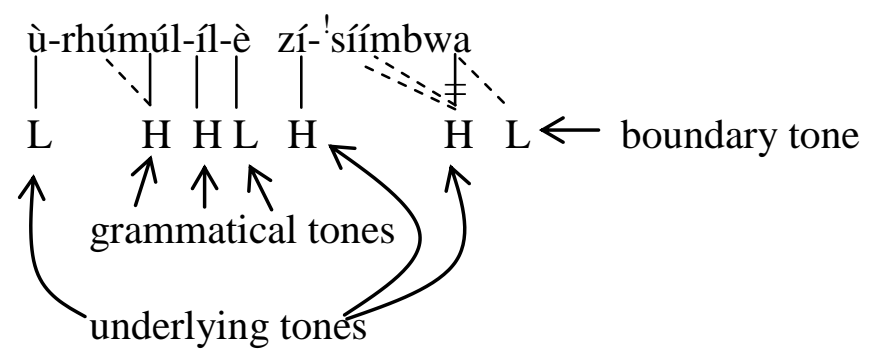

If the verb has fewer than four moras, then the $\mathrm{H}$ tone of the subjunctive is assigned to the final mora of the verb. This leaves no free mora to which the L of the subjunctive can associate, so it is left unassociated. When the following word, e.g. an object noun, begins with a $\mathrm{H}$ tone, then the unassociated $\mathrm{L}$ tone of the subjunctive is manifested as a downstep on the initial $\mathrm{H}$ of the following word. Examples of this are seen in (37).

$$
\begin{array}{ll}
\text { ù-jíing-é 'lí!dúúma } & \text { 'carry corn (subj.)' } \\
\text { ù-léérh-é !lí'dúúma } & \text { 'bring corn (subj.)' } \\
\text { ù-gúl-1́z-é !líddúúma } & \text { 'sell corn (subj.)' } \\
\text { ù-rhúmúl-é !lí 'dúúma } & \text { 'hit corn (subj.)' }
\end{array}
$$

(38) is a schematization of how the $\mathrm{H}$ tone of the subjunctive associates to a verb with only three moras, leaving the L tone floating after the verb.

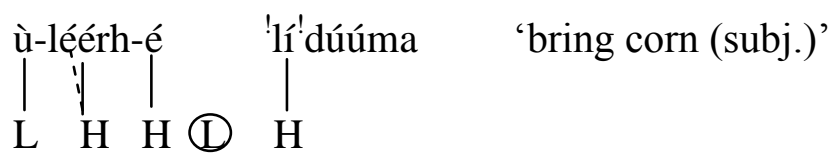

Another instance of grammatically conditioned downstep occurs in the hodiernal perfective. For toneless verbs, this tense is marked by a $\mathrm{H}$ tone assigned to the second mora of the verb, and a $\mathrm{L}$ tone assigned to the final mora of the verb. An example of this is shown in (39). The linked L can be diagnosed by the fact that the initial $\mathrm{H}$ tone on líd dúma fails to spread onto the verb, since HTA is otherwise unbounded.

$$
\text { và-syéél-ì lí!dúúma 'they ground corn’ }
$$


When the verb has only two moras, then the $\mathrm{H}$ tone associates to the second mora, leaving no toneless moras for the L tone. In this situation, the L tone remains unassociated, and this results in a downstep when the following word is H-initial. An example of this can be seen in (40).

$$
\text { và-lól-1́ 'lí! dúúma 'they saw corn’ }
$$

Example (41) shows how the grammatical tones of the hodiernal perfective result in a downstep.

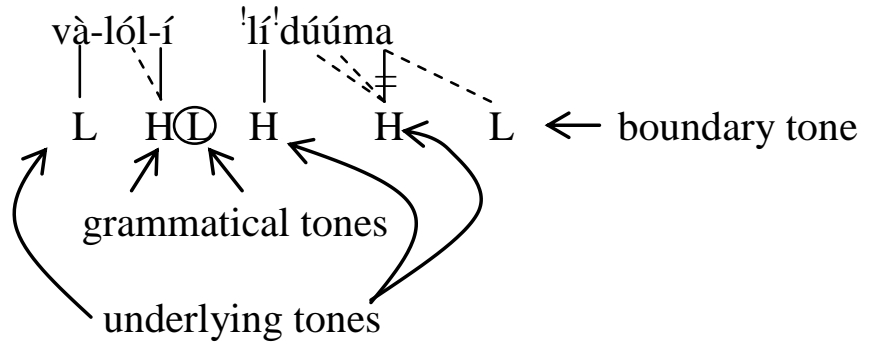

Thus, downstep in Tiriki arises in two ways: when the phonology causes $H$ tones to be adjacent in the output where they were non-adjacent in the input, and when a grammatically assigned $\mathrm{L}$ tone is left unassociated in the output between two linked $\mathrm{H}$ tones. As has been shown, our analysis of downstep as resulting from an unlinked L between linked $\mathrm{H}$ tones captures both types of downstep in Tiriki. The ordered rules that have been presented in this section are summarized in (42). As has been discussed, the relative ordering of these rules is crucial to the analysis, with the exception of Meeussen's Rule with Low Tone Insertion, and Low Tone Linking with Final Lowering. These two pairs of rules have no potential to interact directly, so we have no evidence as to their relative ordering.

Tone rules of Tiriki

Meeussen's Rule > High Tone Linking > High Tone Anticipation > Low Tone Linking Low Tone Insertion

Final Lowering

This concludes our Floating-L analysis of the tone system of Tiriki. We have shown that the floating-L model allows for a principled account of downstep in this language. Additionally, it unifies (non-automatic) downstep with the downdrift that occurs in linked HLH sequences (which itself is well established in many languages). Thus the relationship between these two surface phonetic patterns is not coincidental, but instead follows straightforwardly from their phonological representations.

\subsection{An alternative approach}

Before moving on to discuss how our Floating-L approach extends to other languages, we will briefly discuss how the Separate-H approach would work for Tiriki and contrast it with our own analysis.

A coherent Separate-H analysis is possible for the Tiriki facts presented above. ${ }^{17}$ The key to the analysis is a very early $\mathrm{H}$ tone fusion rule, given in (43).

\footnotetext{
${ }^{17} \mathrm{We}$ thank an anonymous reviewer for helpful suggestions regarding the Separate-H analysis presented here.
} 


\section{H Tone Fusion}<smiles>[AlH][AlH][AlH]</smiles>

If fusion applies before all other rules that are relevant to tone except for Meeussen's Rule, ${ }^{18}$ then later rules causing $\mathrm{H}$ tones to become adjacent to each other will result in downsteps between the Hs since no further fusion will occur. Below is a sample derivation for vaa-mú'mólóm-éél-é mú-lína 'they have just spoken for a friend' (cf. (24) above).

Underlying form

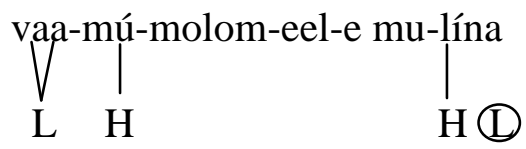

H Tone Fusion

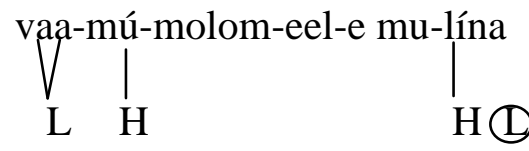

(no change)

High Tone Anticipation

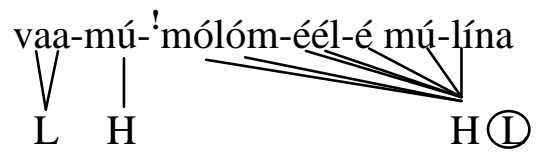

Low Tone Linking

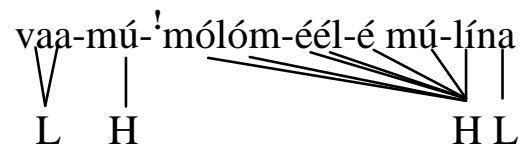

To our knowledge, no counterexamples to this analysis are attested in Tiriki. Hence, relative to our own Floating-L analysis, it is equally compatible with the data. However, there are a number of grounds on which the Separate-H analysis might be rejected in favor of the Floating-L analysis.

First, the Separate-H analysis requires an extra rule ( $\mathrm{H}$ Tone Fusion) in comparison to the Floating-L analysis. One might argue that the Separate-H analysis does not require Low Tone Insertion, and that therefore the two analyses propose an equal number of rules. However, default L tones must be inserted at some point in the phonology (if only at the very end of the derivation) in order for toneless elements to be realized with L tone. As discussed earlier, we reject the notion that this $\mathrm{L}$ tone insertion (or realization) could be carried out completely within the phonetic component of the grammar.

A second, related way in which the Separate-H analysis of Tiriki falls short is that the addition of the fusion rule does not "buy" anything in terms of eliminating the L tone from the phonology. Apart from their proposed role in producing downsteps, phonological L tones are independently needed in the grammar as markers of certain verbal categories, such as the subjunctive and hodiernal perfective, discussed earlier. They are also needed to account for

\footnotetext{
${ }^{18}$ Meeussen's Rule must precede H Tone Fusion in order to account for examples such as xú-múu-rhùmm- $a$ 'to send $\mathrm{him} /$ her', where the lexical $\mathrm{H}$ tone of the verb changes to $\mathrm{L}$ when preceded by a H-toned prefix. If $\mathrm{H}$ Tone Fusion applied first, the lexical $\mathrm{H}$ of the verb root would fuse with the prefix $\mathrm{H}$, incorrectly yielding a $\mathrm{H}$ tone on the verb root.
} 
morphemes that have invariant, prespecified L tones (e.g., the class 2 subject prefix và-, and nouns like xálì 'wife'). Recall from footnote 6 that these prespecified lexical L tones could be reanalyzed as resulting from Meeussen's Rule, since they are always preceded by $\mathrm{H}$ tones. Notice, however, that in the Separate-H analysis, Meeussen's Rule itself must insert a L tone, since Meeussen's Rule must apply before H Tone Fusion and therefore before H Tone Anticipation. Thus, even if we eliminate underlying $L$ tones from lexical items, we cannot eliminate them from the phonology since we still must have multiple phonological rules that refer to L tones.

A final way in which the Floating-L analysis is superior to the Separate-H analysis of Tiriki is that, as discussed earlier, the Floating- $\mathrm{L}$ analysis treats downdrift and downstep from all sources as having the same phonological representation: a L tone between two $\mathrm{H}$ tones. The Separate- $\mathrm{H}$ analysis, on the other hand, has two different ways of generating lowered $\mathrm{H}$ tones: downstep arises via the phonetic interpretation of non-fused $\mathrm{H}$ tones, while downdrift occurs when there is a L tone between two $\mathrm{H}$ tones. Notice that in the case of morphologically triggered downstep (as in subjunctive and hodiernal perfective verbs), the alternation between L tones and downsteps is not captured. In a form like và-lól-í 'lí'dúuma 'they saw corn (hodiernal perfective)', the Floating- $\mathrm{L}$ analysis treats the downstep before the noun as coming from the same grammatical $L$ tone that produces a verb-final surface $L$ tone in longer verbs such as vàsyéél-ì lí̀dúma 'they ground corn (hodiernal perfective)'. In the Separate-H analysis, on the other hand, the downstep before the noun in và-lól-íl lí̀ dúuma would arise from the fact that a grammatical $\mathrm{H}$ tone is assigned to the verb-final mora after $\mathrm{H}$ Tone Fusion has already applied. The presence of a grammatical floating L tone after the verb at the precise site where downstep is observed would be completely coincidental in the Separate- $\mathrm{H}$ analysis. We take this as a disadvantage of the Separate-H approach for Tiriki.

In summary, a Separate-H analysis is possible for Tiriki, but we have argued (largely based on analytical economy) that the Floating-L analysis is superior. In the following section we discuss the extent to which the Floating-L account successfully accounts for languages other than Tiriki.

\section{Downstep in Other Languages}

Having argued for the superiority of a Floating-L analysis of downstep for Tiriki, it remains for us to discuss the extent to which the Floating-L analysis extends to other languages. While we have argued that downstep is caused by floating L tones in Tiriki, it could be caused by other configurations (such as separate $\mathrm{H}$ tones) in other languages. It is far beyond the scope of this paper to present a reanalysis of every language in which downstep has been analyzed as resulting from something other than floating $L$ tones. However, in this section we use some evidence from other languages to show that some languages previously analyzed as having Separate- $\mathrm{H}$ downstep are better analyzed as having Floating-L downstep once we accept the possibility that default $\mathrm{L}$ insertion can be a genuine phonological process. Specifically, we show how Namwanga (Bickmore 2000) and Lumarachi (Marlo 2007) exemplify tone systems predicted by our analysis.

Our analysis correctly predicts the existence of tone systems similar to Tiriki in other languages. In fact, Namwanga (Bickmore 2000) exemplifies one prediction of our analysis perhaps even more clearly than Tiriki does. We have shown how our analysis accounts for downstep in derived-adjacent $\mathrm{H}+\mathrm{H}$ sequences by inserting $\mathrm{L}$ tones not just anywhere between $\mathrm{H}$ 
tones, but only where there are toneless moras. This works fairly straightforwardly in Tiriki, except that Meeussen's Rule interferes with our ability to test the prediction that $\mathrm{H}$ tones becoming adjacent via syntax or morphology should not exhibit downstep (though, as we showed, the prediction is upheld in the places where we are able to test it). In Namwanga, Meeussen's Rule does not interfere, so there is an even clearer generalization in Namwanga than in Tiriki: phonologically derived sequences of adjacent $\mathrm{H}$ tones exhibit downstep, while other sequences of $\mathrm{H}$ tones do not.

We illustrate these points in (45) and (46). In (45), two $\mathrm{H}$ tones come together through spreading and result in downstep, as in Tiriki (examples are from Bickmore 2000 with page numbers given; note that $\mathrm{H}$ spreading in Namwanga is left-to-right).

(45) $\quad \mathrm{H}$ tones become adjacent via spreading (Namwanga)

$$
\begin{aligned}
& \text { ú-kú-'wá-sákúúl-à 'to comb them' (298) tú-lí-'wáá-péèl-á 'we will shave them' (316) } \\
& \text { ú-kú-'léét-à 'to bring' (298) tú-lí-'léét-á 'we will bring' (316) }
\end{aligned}
$$

(46) shows examples of where $\mathrm{H}$ tones are input-adjacent; these surface as level sequences of $\mathrm{H}$ tones.

(46) $\mathrm{H}$ tones are adjacent in the input (Namwanga)

$$
\text { ú-kú-'wáa-wándúl-íll-à } \quad \text { 'to blacksmith for them' (303) }
$$

tù-ngá-wándúl-ì̀l-

Our analysis can be applied straightforwardly to Namwanga: default L tones licensed by the toneless TBUs are responsible for downstep in (45), but the absence of intervening L-licensors in (46) accounts for the lack of downstep in that context. Thus, the existence of the Namwanga tone system is completely consistent with our analysis even though Bickmore (2000) proposed a different account.

In Bickmore's analysis, a sequence of $H$ tones is phonetically interpreted as having a downstep. Thus words like in (45) have the output representation in (47a), which is selected by OT constraints enforcing spreading. However, in words like in (46), the output cannot have separate adjacent $\mathrm{H}$ tones. Constraints are needed to drive fusion of $\mathrm{H}$ tones in non-downstep contexts, and the desired representation is the one in (47b).
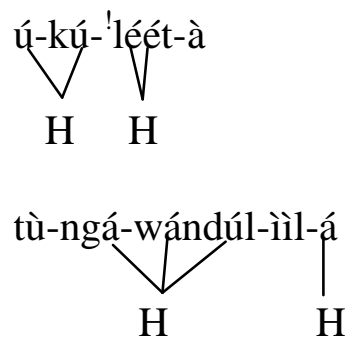

In Bickmore's analysis, downstep is driven by the constraint UNIFORMITY, which penalizes the fusion of adjacent $\mathrm{H}$ tones. Bickmore shows that UNIFORMITY needs to be parametrized in order not to incorrectly predict downstep when $\mathrm{H}$ tones are adjacent in the input. Fusion of $\mathrm{H}$ tones that were not adjacent in the input needs to be penalized more heavily than fusion of tones that are 
adjacent in the input: in other words, UNIF(NON-ADJACENT) is ranked above other UNIFORMITY constraints.

The fundamental difference between our Floating- $\mathrm{L}$ analysis and this Separate-H analysis is that in our analysis, downstep on underlyingly toneless TBUs in the HTA context is due to the same default $\mathrm{L}$ that is pronounced overtly in the absence of a spreading $\mathrm{H}$ tone. This is a distinct advantage in that the insertion of the L tones causing downstep is independently motivated, and our analysis is able to predict the exact locations in which these floating L tones will occur. Conversely, the Separate-H analysis of Namwanga must stipulate conditions on adjacency, and it fails to explain why it is more important to preserve the distinctness of non input-adjacent elements than input-adjacent ones. There is no reason built into the analysis for why the situation could not be reversed; that is, a constraint UNIF(ADJACENT) could have been proposed, resulting in a system that preferentially distinguishes input-adjacent tones but allows non input-adjacent tones to be fused. We know of no such system. A more explanatory generalization is that the adjacency conditions are an epiphenomenon arising from the presence or absence of TBUs that can license the $\mathrm{L}$ tone necessary to trigger downstep.

Another interesting prediction is made by our analysis as a consequence of the fact that default L tone insertion does not occur at the level of phonetic interpretation but is rather a fullfledged, orderable phonological rule. In Tiriki, L tone insertion applies at the very beginning of the derivation so that all sequences of toneless moras project a L tone, but in some other slightly different language, $\mathrm{L}$ tone insertion should be able to apply later in such a way that $\mathrm{H}$ tones that come together via certain (late) phonological or morphological rules should exhibit downstep, while $\mathrm{H}$ tones that come together via other (early) rules would show no downstep because these rules would eliminate the sequences of toneless moras that trigger $\mathrm{L}$ tone insertion. ${ }^{19}$

This is precisely the situation that is found in Lumarachi (Marlo 2007), a Bantu language of the Luyia subgroup, to which Tiriki also belongs. ${ }^{20}$ In Lumarachi, as in Tiriki, when H tones at word edges become adjacent due to syntax, there is no downstep between the two $\mathrm{H}$ tones. For example, (48) shows verbs in the near future, a tense that triggers Melodic H Assignment at the right edge of the verb stem (Marlo 2007: 46). This can be seen in (48a). As shown in (48b), when the object noun has initial $\mathrm{H}$ tone, there is no downstep between the final $\mathrm{H}$ of the verb and the initial $\mathrm{H}$ of the noun.

a-lá-lól-á namukuru

'he will see Namukuru'

a-lá-réébh-á namukuru

'he will ask Namukuru'

a-lá-lékhúúl-á namukuru

'he will release Namukuru'

a-lá-khwéésúlúl-á namukuru

'he will drag Namukuru'

(48b)
a-lá-lól-á málóbhá
'he will see Maloba'
a-lá-réébh-á málóbhá
'he will ask Maloba'
a-lá-lékhúúl-á málóbhá
'he will release Maloba'
a-lá-khwéésúlúl-á málóbhá
'he will drag Maloba'

\footnotetext{
${ }^{19}$ cf. Ito, Mester, and Padgett's (1995: 572ff) discussion of underspecification paradoxes, where they raise the possibility of default feature insertion as an orderable rule (though ultimately they reject this approach).

${ }^{20}$ Thanks to Michael Marlo for discussion of this case. In the examples to follow, we focus only on underlyingly toneless verbs, since the underlying tones of H-toned verbs interact with melodic H's in a way that would complicate the discussion. Note that the Lumarachi analysis given here is different from Marlo's (2007), but as far as we have been able to discern, both analyses are equally compatible with the data.
} 
We can account for this by assuming that this Melodic $\mathrm{H}$ Assignment rule applies early, before Default L Insertion.

Another early rule that causes $\mathrm{H}$ tones to come together with no downstep is unbounded Rightward H Spreading that applies in phrasal contexts to verbs in certain tenses, causing verbs to surface with all $\mathrm{H}$ tones. One such tense is the indefinite future (Marlo 2007: 77). In this tense, a second type of Melodic $\mathrm{H}$ Assignment applies (in this case, assigning $\mathrm{H}$ to the the left edge of the stem), and the $\mathrm{H}$ spreads all the way to the right edge of the stem. This is shown in (49a). As can be seen in (49b), when a H-initial object noun follows the verb, there is no downstep between the final $\mathrm{H}$ of the verb and the initial $\mathrm{H}$ of the object.

$\begin{array}{ll}\text { (49a) } \begin{array}{l}\text { a-li-lól-á namukuru } \\ \text { a-li-lékhúúl-á namukuru } \\ \text { a-li-sáámbúl-ír-á namukuru }\end{array} & \begin{array}{l}\text { 'he will see Namukuru' } \\ \text { 'he will release Namukuru' } \\ \text { 'he will remove the roof for Namukuru' }\end{array} \\ \begin{array}{ll}\text { (49b) } & \text { a-li-lól-á málóbhá } \\ \text { a-li-lékhúúl-á málóbhá } & \text { 'he will see Maloba' } \\ \text { a-li-sáámbúl-ír-á málóbhá }\end{array} & \begin{array}{l}\text { 'he will release Maloba' } \\ \text { 'he will remove the roof for Maloba' }\end{array}\end{array}$

Again, we can explain this pattern if both Melodic H Assignment and the unbounded Rightward $\mathrm{H}$ Spreading rule are ordered before Default L Insertion.

A different process in Lumarachi does produce a downstep between verbs and object nouns, confirming a prediction of our analysis. In the subjunctive, verbs are assigned a $\mathrm{H}$ tone on the first mora of the second syllable of the stem, and this $\mathrm{H}$ later undergoes a bounded Rightward $\mathrm{H}$ Spreading rule, which spreads the $\mathrm{H}$ one mora to the right. When the verb is short enough so that it ends up being $\mathrm{H}$-final (i.e., when Melodic $\mathrm{H}$ Assignment puts the $\mathrm{H}$ on the final vowel, or when the bounded spreading rule ends up taking the $\mathrm{H}$ tone all the way to the right edge of the stem), an initial $\mathrm{H}$ on a following noun will be downstepped, as shown in (50) (Marlo 2007: 497).
khu-reebh-é 'málóbhá
'let's ask Maloba'
khu-lim-ír-é 'málóbhá
'let's dig for Maloba'

The boundedness of the $\mathrm{H}$ Spreading rule is illustrated in the subjunctive examples in (51) (Marlo 2007: 497), where the verbs are long enough so that spreading the $\mathrm{H}$ one mora to the right does not spread it all the way to the final vowel of the verb; in these cases, the remaining moras between the target of $\mathrm{H}$ Spreading and the end of the verb have L tone on the surface.
khu-lekhúúl-e málóbhá
'let's release Maloba'
khu-saambúl-ír-e málóbhá
'let's remove the roof for Maloba'
khu-lomálóm-er-e málóbhá
'let's talk for Maloba'

The examples in (52) (Marlo 2007: 47), where the object 'Maloba' follows a verb with final $\mathrm{H}$ tone in the near future tense, confirm that 'Maloba' has $\mathrm{H}$ tone and that the downstep in (50) is not inherent to the object. 

a-lá-lól-á málóbhá
'he will see Maloba'
a-lá-lékhúúl-á málóbhá
'he will release Maloba'
a-lá-khwéésúlúl-á málóbhá
'he will drag Maloba'

The downstep in the subjunctive can be explained via rule ordering. First, a default floating $\mathrm{L}$ is assigned to the toneless verb, then the $\mathrm{H}$ tone of the subjunctive is assigned to the first mora of the second syllable of the stem (and spreads once to the right, where applicable). This 'sandwiches' the floating L tone between the melodic $\mathrm{H}$ and the initial $\mathrm{H}$ of a following noun, giving rise to a downstep. The ordering of processes discussed here would be as in (53).

(53) Near Future Melodic H Assignment, Indefinite Future Melodic H Assignment

Unbounded Rightward H Spreading

Default L Insertion

Subjunctive Melodic H Assignment

Bounded Rightward H Spreading

Thus, the difference in downstep vs. no downstep between the subjunctive on the one hand and the near future and indefinite future on the other hand can be attributed to the fact that the rules assigning and spreading the melodic $\mathrm{H}$ tones in the near future and indefinite future are ordered before Default L Insertion, while the rules assigning and spreading the melodic $\mathrm{H}$ in the subjunctive apply after Default L Insertion. The existence of languages like Lumarachi and Namwanga, as described above, is predicted by, and therefore provides one argument in favor of, our analysis.

The Floating-L analysis also works for languages that are more different from Tiriki. In some languages, there does not appear to be any phonological source for the floating L tones that we propose to cause downsteps. However, we will demonstrate here that a typical language of this type is still able to be reanalyzed using the Floating-L configuration - in general, the Floating-L account and the Separate-H account are equally compatible with the data for these languages. A strong universalist view would hold that there should be only one phonological representation of downstep cross-linguistically. If the goal of feature geometry is to establish representational configurations that make predictions about the interaction of specific features in different languages, then identifying a single, universal representation of a particular commonly recurring sound phenomenon (in this case, downstep) would constitute an advancement within the theory. We do not necessarily wish to argue for this view here, but for those who do subscribe to it, we would like to point out that if only one of the two approaches to downstep is to be used for all languages, it should be the Floating-L approach rather than the Separate-H approach. This is because the Floating-L approach can be extended to account not only for Tiriki but also for other languages, while the same cannot be said for the Separate-H approach. In that model we would have to stipulate, for Tiriki and languages like it, that $\mathrm{H}$ tones that become adjacent due to syntax fuse into a single $\mathrm{H}$, while those that come together in the phonology do not fuse. It does not seem that this could be handled simply through the correct ordering of fusion with other rules. If anything, it would be easier to explain the exact opposite situation in which downstep occurs when $\mathrm{H}$ tones come together via syntax, while no downstep occurs when $\mathrm{H}$ tones come together via phonology. ${ }^{21}$ In any case, in what follows here, we will show the kind of reanalysis that

\footnotetext{
${ }^{21}$ In that case we could propose a fusion rule that applies late in the phonological derivation such that $\mathrm{H}$ tones that became adjacent in the phonology would fuse; later, at the postlexical level when phonological adjacency across
} 
would be necessary in order to bring the languages previously analyzed using the Separate- $\mathrm{H}$ approach into conformity with the Floating-L model.

Odden (1982) analyzes Shambaa as exhibiting downstep any time two H tones come together without fusing into a single $\mathrm{H}$ (fusion occurs in a very limited environment, namely, when '...a $\mathrm{H}$ toned object prefix stands before a H toned verb stem of two or more syllables' (Odden 1982: 191)). Example (54) shows some instances of downstep in Shambaa (Odden 1982: 187-188). In each example, downstep occurs in a location where two $\mathrm{H}$ tones are adjacent with no plausible source for an intervening lexical or grammatical floating $\mathrm{L}$ tone.

(54a) Between words

nwáná 'dú 'only a child'

ní 'kúi 'it is a dog'

(54b) Between morphemes

ú-'wá-lól-e 'you should look at them'

a-té-'kóm-á 'he killed (vf)'

Example (55) shows cases where $\mathrm{H}$ tones come together without a downstep; these exemplify the limited environment for fusion described above (Odden 1982: 191). In any other context, a downstep would be expected before the H-toned verb root kóm when preceded by a H-toned morpheme.
ní-kí-'chí-kóm-á
'I was killing it (cl. 7)'
a-ngé-'chí-kóm-á
'he should have killed it (cl. 7)'
ku-wá-kóm-á
'to kill them'

Odden's analysis of this pattern (1982: 191-192) is that the Separate-H configuration results in downstep, and when there is no downstep, this is because the two $\mathrm{H}$ tones fuse into a single $\mathrm{H}$. The analysis can be schematized as in (56).

(56a) Downstep $\left[\mathrm{H}^{\prime} \mathrm{H}\right]$<smiles>C[Al]=[Al]C</smiles>

$\mathrm{H} \quad \mathrm{H}$

(56b) No downstep $[\mathrm{HH}]$<smiles>C</smiles>

A simple readjustment reconciles this analysis with our Floating-L claim. Instead of the configurations in (56), we propose that the representations for $\left[\mathrm{H}^{\prime} \mathrm{H}\right]$ and $[\mathrm{HH}]$, respectively, are as shown in (57a) and (57b).

word boundaries becomes meaningful, we would have sequences of $\mathrm{H}$ tones that had not undergone the fusion rule and therefore would get a downstep between them. 
(57a)

Downstep $\left[\mathrm{H}^{\prime} \mathrm{H}\right]$

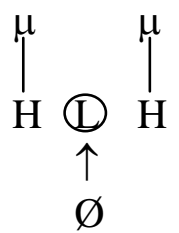

(57b) No downstep $[\mathrm{HH}]$<smiles>C=[VH2]</smiles>

Thus, the change in the revised analysis is that the configuration $\mathrm{H}+\mathrm{H}$ triggers a (late) phonological rule that inserts a $\mathrm{L}$ tone between the $\mathrm{H}$ tones, resulting in a downstep on the second $\mathrm{H}$.

A possible objection to our alternative analysis is that perhaps there is no phonologically active L tone in Shambaa, in which case the insertion rule that creates downsteps would be too abstract because it inserts a feature that is otherwise not phonologically motivated in the language. However, postlexical rules do not have to be limited to the inventory of phonologically contrastive features in languages. Therefore, the lack of underlying $\mathrm{L}$ tone in Shambaa does not preclude a postlexical rule inserting a $\mathrm{L}$ tone in certain contexts.

A second possible objection is that our reanalysis with floating $\mathrm{L}$ tones is more complicated than the original analysis. But although the new analysis has one more rule than Odden's analysis, this does not necessarily indicate that the reanalysis is more complex. One could argue that requiring the phonetic component to interpret a $\mathrm{H}$ tone as being lowered after another $\mathrm{H}$ tone adds complexity to the phonetic grammar with respect to the floating- $\mathrm{L}$ analysis, which requires only the more natural phonetic interpretation of a $\mathrm{H}$ as being lowered after $\mathrm{L}$. Thus, it is not obvious which analysis is more complex.

In any case, the floating-L analysis is at the very least plausible, if not preferable, for Shambaa. We speculate that the same type of reanalysis would be equally easy to implement in any other language with downstep previously analyzed via the Separate-H representation. To give a second brief example, Supyire, a Gur language of southeastern Mali, is another language where downstep has been analyzed as phonetic realization of adjacent $\mathrm{H}$ tones without any influence from L tones (Carlson 1983). In Supyire, downstep takes place only between words where the first ends with $\mathrm{H}$ and the second begins with $\mathrm{H}$ (downstep within words is unattested). However, the presence of downstep depends on the grammatical categories of the words involved. When the words involved belong to non-downstepping grammatical categories, an additional rule parametrized for these categories provides for a process of Fusion. In our approach, we could propose that words of the downstepping categories have underlying final floating $L$ tones that cause the downstep. This would achieve the same effect as having a rule of Fusion triggered only by words in certain (non-downstepping) categories, and would be no more stipulative. In general, Floating-L reanalyses of languages like Shambaa and Supyire can only be argued against on grounds of elegance (see, e.g., Gussenhoven 2004: 104) since they capture the empirical facts about these languages equally as well as do the Separate- $\mathrm{H}$ analyses. But the reverse does not hold: as we have argued, a Separate-H analysis does not adequately predict the contexts in which downstep occurs in a language like Tiriki. 


\section{Conclusion}

So far we have argued that the Floating-L analysis (along with our proposal that default L tone insertion is a regular, orderable phonological rule) is superior to the Separate-H analysis for languages like Tiriki, and we have shown that it is at least compatible with the data from languages previously analyzed as having the Separate-H downstep configuration. But of course these are not the only proposals in the literature for the analysis of downstep. Apart from the Floating-L and Separate-H proposals, there have been numerous other proposals for analyzing downstep, some of which share with our analysis the characteristic that downstep arises from a phonological instruction to lower pitch, rather than entirely within phonetic implementation. To conclude the paper, we give a brief overview of some other previous proposals for analyzing downstep and discuss the extent to which our approach is compatible with those proposals.

One proposal is that downstep is caused by register features (see, e.g., Hyman 1985, 1986b, 1993 b, Snider 1990, 1999). ${ }^{22}$ Though the details of the proposals vary, the central idea is that every tone consists of a node linked to as many as two tone features - a tone feature (the familiar $\mathrm{H}$ and L) and a high or low register feature (abbreviated by, e.g., Snider 1990 as $h$ and $l$, respectively). In a two-tone language, $\mathrm{H}$ tones have the tone feature $[\mathrm{H}]$ and the register feature [h], while L tones have [L] and [1] (see Snider 1999 for discussion of whether or not both tone and register features are specified underlyingly). Downstep and downdrift result when the [1] register feature of a $\mathrm{L}$ tone associates to the tonal node of a $\mathrm{H}$ tone, as illustrated below.

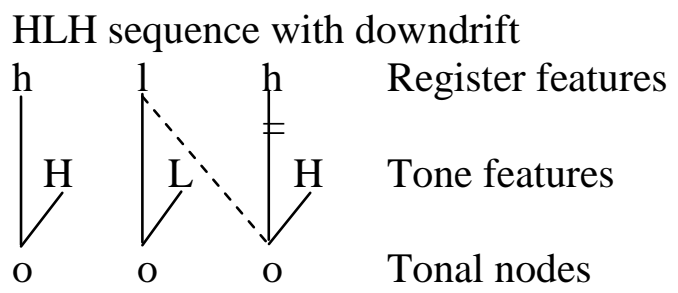

In that approach, then, a downdrifted or downstepped $\mathrm{H}$ tone has a $[\mathrm{H}]$ tone feature and a $[1]$ register feature, differentiating it from a regular non-lowered $\mathrm{H}$ tone with $[\mathrm{H}]$ and $[\mathrm{h}]$. The tone features $[\mathrm{H}]$ and $[\mathrm{L}]$ indicate categorically whether the tone is high or low within a register, while the register features are relative in the sense that $[\mathrm{h}]$ is one step higher than the preceding register and [1] is one step lower (see, e.g., Snider 1990 for discussison). The relative nature of the register features is what allows for sequences of successively downdrifted or downstepped $\mathrm{H}$ tones as in the Shambaa example shown earlier.

The register features proposal, though it is significantly different in appearance from the Floating-L proposal that we advocate, is not as dramatically different in substance. In both approaches, the representation of downstep involves a low tone feature, whether a register feature or a L tone itself. The two primary differences between the register feature proposal and the Floating-L proposal are as follows. First, the register feature proposal assumes two separate features for each tone (i.e., $\mathrm{H}$ tones have both $[\mathrm{H}]$ and $[\mathrm{h}]$ ), whereas the Floating-L proposal makes no explicit assumption about decomposition into tone features. The second difference is that in the register tone approach, downstep and downdrift involve linking of the [1] register

\footnotetext{
${ }^{22}$ Truckenbrodt's (2002) analysis of downstep also involves register, but it is phonetic register rather than phonological. In Truckenbrodt's approach, downstep results from articulatory 'undershoot'.
} 
feature to the tonal node of the lowered $\mathrm{H}$, whereas in the Floating-L approach, it is not necessarily assumed that any part of the $\mathrm{L}$ tone directly associates to the node bearing the lowered $\mathrm{H}$. Hence in the register features approach, both downstep and downdrift require the application of a rule that spreads a low feature onto the $\mathrm{H}$ tone to be lowered. The fact that across languages this process always spreads the low feature onto a following $H$ tone rather than a preceding one must be stipulated and/or have some explanation external to the grammar.

A related model of downstep and downdrift is one in which tone features are arranged hierarchically in such a way that every high tone after a low tone establishes a lower pitch register or 'ceiling' for the tones that follow. Such a model is advanced by Clements (1983). Below is an example of how the hierarchical model captures downdrift, as in a hypothetical utterance schematized in (59) (Clements 1983: 154).

$\mathrm{H}$

\section{$\mathrm{H}$}

$\mathrm{HH}$

LL

$\mathrm{L}$

$\mathrm{HH}$

\section{LLL}

In Clements' model, there are two tonal elements, $h$ and $l$, and the tones of the utterance in (59) would be represented phonologically as in (60) (1983: 155).

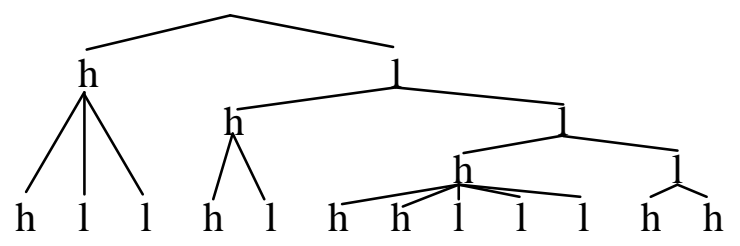

The tree structure is formed via an algorithm that, in effect, creates a new binary branch every time an $h$ follows a $l$ (see Clements 1983 for details). ${ }^{23}$ Any $h$ tone dominated by more $l$ nodes than a preceding $h$ is lower than that $h$. Downstep is represented the same way, as seen below.

\footnotetext{
${ }^{23}$ It is implied that the algorithm is universal, but in fact the algorithm would likely need to be revised to account for languages in which there is downstep but not downdrift. In Clements' algorithm, any $h l \ldots h$ sequence will have a $l$ node dominating the second $h$, resulting in lowering. The algorithm would need to be altered for the languages that lack downdrift so that a new $l$-dominated branch is created only when the triggering $l$ tone is unlinked.
} 
(61a)

Downdrift

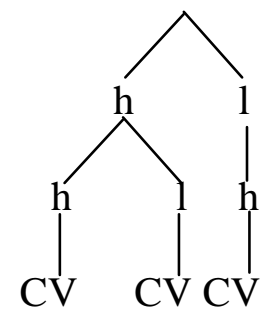

(61b) Downstep

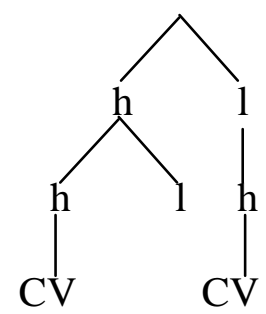

Here it has been our intention to contrast the Floating-L approach specifically with the Separate$\mathrm{H}$ approach. Future research may establish the extent to which the Floating-L approach is compatible with the register feature- or tonal hierarchy-based models.

In this paper, we have given an analysis of downstep in Tiriki and showed that this analysis has important implications for the analysis of downstep in other languages. Our analysis relied on a well-known model of downstep (which we have referred to as the Floating-L approach) in which downstep results from a floating $\mathrm{L}$ tone between two $\mathrm{H}$ tones. In addition to this assumption, our analysis of Tiriki required us to make the further (and, to our knowledge, novel) claim that the insertion of default L tones is a regular phonological rule in the sense that it is not limited to applying at the very end of the phonological derivation but rather can be crucially ordered with respect to other regular, productive phonological rules. This proposal allows for a unified account of downstep in all contexts in Tiriki - a striking result, given the wide variety of ways in which downstep arises in the phonology of the language, which we illustrated in our description of the tone system in $§ 3$. It also allows for an insightful reanalysis of downstep in some other languages, including Namwanga and Lumarachi, and is at least consistent with the data in other languages including Shambaa and Supyire. Future research will explore the question of whether it is possible and/or desirable to extend the Floating-L analysis to all languages exhibiting downstep; regardless, this paper has demonstrated the considerable advantages of the Floating-L model for Tiriki and languages like it.

\section{References}

Bickmore, Lee. 2000. Downstep and fusion in Namwanga. Phonology 17: 297-331.

Carlson, Robert. 1983. Downstep in Supyire. Studies in African Linguistics 14.1: 35-45.

----. 1994. A Grammar of Supyire. New York: Mouton de Gruyter.

Clements, George N. and Kevin C. Ford. 1979. Kikuyu Tone Shift and its Synchronic Consequences. Linguistic Inquiry 10.2: 179-210. 
Clements, George N. 1983. The hierarchical representation of tone features. Pp. 145-176 in I. Dihoff, ed. Current Approaches to African Linguistics 1. Dordrecht: Foris.

-----. 1996. Review of H. van der Hulst and K. Snider, eds. The Phonology of Tone: The Representation of Tonal Register. Language 72.4: 847-852.

Elimelech, Baruch. 1978. A Tonal Grammar of Etsako. Berkeley, California: University of California Publications in Linguistics, vol. 87.

Hombert, Jean-Marie. 1974. Universals of downdrift: Their phonetic basis and significance for a theory of tone. Studies in African Linguistics supplement 5: 169-183.

Hyman, Larry M. 1979a. A reanalysis of tonal downstep. Journal of African Languages and Linguistics 1: 9-29.

-----. 1979b. Tonology of the Babanki noun. Studies in African Linguistics 10.2: 159-178.

-----. 1985. Word domains and downstep in Bamileke-Dschang. Phonology Yearbook 2: 85-138.

-----. 1986a. Downstep deletion in Aghem. Pp. 209-222 in David Odden, ed. Current Approaches to African Linguistics 4. Dordrecht: Foris.

-----. 1986b. The representation of multiple tone heights. Pp. 109-152 in Koen Bogers, Harry van der Hulst, and Maarten Mous, eds. The Phonological Representation of Suprasegmentals. Dordrecht: Foris.

-----. 1993a. Structure preservation and postlexical tonology in Dagbani. Pp. 235-254 in Phonetics and Phonology, Volume 4. Studies in Lexical Phonology.

-----. 1993b. Register tones and tonal geometry. Pp. 75-108 in H. van der Hulst and K. Snider, eds. The Phonology of Tone: The Representation of Tonal Register. Berlin: Mouton de Gruyter.

Hyman, Larry M. and Russell G. Schuh. 1974. Universals of tone rules: Evidence from West Africa. Linguistic Inquiry 5.1: 81-115.

Hyman, Larry M. and Maurice Tadadjeu. 1976. Floating tones in Mbam-Nkam. In L.M. Hyman, ed. Studies in Bantu Tonology. Los Angeles: Southern California Occasional Papers in Linguistics No. 3.

Inkelas, Sharon. 1987. Tone feature geometry. Pp. 223-237 in James Blevins and Julie Carter, eds. Proceedings of the North Eastern Linguistics Society 18. Amherst, Massachusetts: Graduate Student Linguistic Association.

-----. 1998. The theoretical status of morphologically conditioned phonology: A case study from dominance. Yearbook of Morphology 1997: 121-155.

Inkelas, Sharon and William Leben. 1991. Where phonology and phonetics intersect: The case of Hausa intonation. Pp. 17-24 in Mary Beckman and John Kingston, eds. Papers in Laboratory Phonology: Between the Grammar and Physics of Speech. Cambridge: Cambridge University Press.

Inkelas, Sharon, William R. Leben, and Mark Cobler. 1987. The phonology of intonation in Hausa. Pp. 327-342 in James Blevins and Julie Carter, eds. Proceedings of the North Eastern Linguistic Society 17. Amherst, Massachusetts: Graduate Student Linguistic Association.

Inkelas, Sharon, Cemil Orhan Orgun, and Cheryl Zoll. 1997. Implications of lexical exceptions for the nature of grammar. Pp. 393-418 in Iggy Roca, ed. Constraints and derivations in phonology. Oxford: Clarendon Press.

Ito, Junko, Armin Mester, and Jaye Padgett. 1995. Licensing and redundancy: Underspecification in Optimality Theory. Linguistic Inquiry 26: 571-614.

Kaplan, Aaron F. 2008. Iterativity is an Emergent Property of Grammar. PhD. dissertation, UC Santa Cruz. 
Laniran, Yetunde and Chip Gerfen, 1997. High raising, downstep and downdrift in Igbo. In Proceedings of The 71st Annual Meeting of the Linguistic Society of America, Chicago, p. 59.

Leben, William. 1973. Suprasegmental Phonology. PhD. dissertation, MIT.

Leung, Elizabeth. The tonal phonology of Llogoori: a study of Llogoori verbs. Working Papers of the Cornell Phonetics Lab 6.

Liberman, Mark and Janet Pierrehumbert. 1984. Intonational invariance under changes in pitch range and length. In M. Aronoff and R. T. Oehrle, eds., Language Sound Structure: Studies in Phonology Presented to Morris Halle. Cambridge, Massachusetts: MIT Press. Pages 157233.

Marlo, Michael. 2007. The Verbal Tonology of Lunyala and Lumarachi: Two Dialects of Luluyia (Bantu, J.30, Kenya). PhD. dissertation, University of Michigan.

Marlo, Michael and David Odden. 2005. Tone melodies in Llogoori. Paper presented at the MidContinental Workshop on Phonology (MCWOP), University of Michigan.

Myers, Scott. 1998. Surface underspecification of tone in Chichewa. Phonology 15: 367-391.

Odden, David. 1982. Tonal phenomena in Shambaa. Studies in African Linguistics 13.2: 177208.

-----. 1988. Floating tones and contour tones in Kenyang. Studies in African Linguistics 19.1: 134.

Paster, Mary. 2003. Floating tones in Gã. Studies in African Linguistics 32.1: 17-39.

Pulleyblank, Douglas. 1986. Tone in Lexical Phonology. Dordrecht: Riedel.

Schachter, Paul. 1961. Phonetic similarity in tonemic analysis. Language 37: 231-238.

Schuh, Russell. 1971. Verb forms and verb aspects in Ngizim. Journal of African Languages 10: 47-60.

----. 1978. Tone rules. Pp. 221-256 in Fromkin, V., ed. Tone: A Linguistic Survey. Academic Press.

Silverstein, Raymond O. 1976. A strategy for utterance production in Hausa. Studies in African Linguistics Supplement 6: 233-241.

Snider, Keith. 1990. Tonal upstep in Krachi: Evidence for a register tier. Language 66.3: 453474.

-----. 1999. The geometry and features of tone. Dallas: Summer Institute of Linguistics and University of Texas at Arlington.

Truckenbrodt, Hubert. 2002. Upstep and embedded register levels. Phonology 19: 77-120.

van der Hulst, Harry and Keith Snider. 1993. Issues in the representation of tonal register. Pp. 127 in H. van der Hulst and K. Snider, eds. The Phonology of Tone: The Representation of Tonal Register. Berlin: Mouton de Gruyter.

Winston, F.D.D. 1960. The 'mid tone' in Efik. African Language Studies 1: 185-192.

Yip, Moira. 2002. Tone. Cambridge Textbooks in Linguistics. Cambridge: Cambridge University Press. 
Authors' contact information:

Mary Paster

Department of Linguistics and Cognitive Science

Pomona College

Mary.Paster@pomona.edu

Yuni Kim

Department of Linguistics and English Language

University of Manchester

Oxford Road

Manchester M13 9PL

United Kingdom

yuni.kim@manchester.ac.uk 